No $2011-24$

December

Lionel Fontagné Amélie Guillin Cristina Mitaritonna

We acknowledge financial support from the CIREM. 


\section{TABLE OF CONTENTS}

Non-technical summary. . . . . . . . . . . . . . . . . . . . . . . . . . . 3

Abstract . . . . . . . . . . . . . . . . . . . . . . . . . . . . 5

Résumé non technique . . . . . . . . . . . . . . . . . . . . . . . . . 6

Résumé court . . . . . . . . . . . . . . . . . . . . . . . 7

1. Introduction . . . . . . . . . . . . . . . . . . . . . . . . . 8

2. Quantifying trade barriers in services . . . . . . . . . . . . . . . . 10

3. Data . . . . . . . . . . . . . . . . . . . . . . . 13

4. Methodology . . . . . . . . . . . . . . . . . . . . . . . . 14

4.1. Gravity equations estimated on cross-sectional reconstructed data . . . . . . . 14

4.2. Gravity equations estimated using actual panel data. . . . . . . . . . . . . 16

4.3. Derivation of tariff equivalents . . . . . . . . . . . . . . . . . . . . . 17

5. Estimation results. . . . . . . . . . . . . . . . . . . . . . . . . . . . 19

5.1. Beyond Park's specification: regression results on (cross section) reconstructed data. . . . . . . . . . . . . . . . . . . . . . . 19

5.2. Considering the zero flows . . . . . . . . . . . . . . . . . . . 21

5.3. Regression results from estimations on actual data . . . . . . . . . . . . . 23

6. Tariff equivalents . . . . . . . . . . . . . . . . . . . . . . . 24

7. Conclusion . . . . . . . . . . . . . . . . . . . . . . . 30

References . . . . . . . . . . . . . . . . . . 31

8. Appendix . . . . . . . . . . . . . . . . . . . . . . . . . . . . . . 33

8.1. Cross section estimations using GTAP data . . . . . . . . . . . . . . . . 33

8.2. Ad-valorem equivalents by country from cross section estimations using GTAP data. . . . . . . . . . . . . . . . . . . . . 38

8.3. Reliability . . . . . . . . . . . . . . . . . . . 40

8.4. RTAs . . . . . . . . . . . . . . . . . . . . . 42

List of working papers released by CEPII . . . . . . . . . . . . . . . . . . . 43 


\section{ESTIMATIONS OF TARIFF EQUIVALENTS FOR THE SERVICES SECTORS}

\section{NON-TECHNICAL SUMMARY}

Services is the largest sector in the global economy, representing $70 \%$ of world added value and over half of total employment. However its share in total international trade is only $21 \%$, in part due to the high level of regulatory protection in domestic markets for services. Simulations relying on Computable General Equilibrium (CGE) modeling point to large gains associated with the partial liberalization of services in the rich economies, but also in some developing countries. Since these estimations rely on tariff equivalents of protection on services, accurate measure of the level of protection on services are a crucial issue for policy makers.

One problem lies in the specific nature of services compared to goods. Proximity between producer and consumer and the intangible characteristics intrinsic to services produce different impediments to trade in services from those that apply to goods. They include limitations such as quotas, licences, interdictions of some activities to foreigners, and government regulations designed to reduce market access to foreign services and/or discriminate in favor of domestic firms. Hence, liberalizing national trade in services essentially requires a change in national regulation. Identifying the actual tariff equivalents of these regulations is not straightforward. Data on actual policies are scarce and transforming qualitative information into a quantitative measure of protection is difficult. Therefore, we depart from the inventory approach used to build indexes of the restrictiveness of policies in the service sector, and also from the so-called two-stage method, in which information on barriers faced by exporters of services on their destination markets is used to explain international differences in price-cost margins within the services sectors.

The context is appropriate for an indirect approach consisting of computing tariff equivalents and revealing protection by comparing actual trade in services against a benchmark. The distribution of the residuals of a gravity equation estimated at the sectoral level can be used for this computation; alternatively, we can compute the average protection applied by each importer, from the importer fixed effects coefficients. We employ this latter procedure, which is an improvement on the methodology of Park (2002). We compute regulation tariff equivalents focusing on cross border trade in services (Mode 1) and provide evidence on the magnitude of the different estimation biases potentially associated with this method.

We provide tariffs equivalents for 9 services sectors and 65 countries based on Global Trade Analysis Project (GTAP) data. The countries with the lowest levels of protection are the developed economies. The most liberalized sector is Transport with a 26\% tariff protection on average. The most protected is Construction, with an average tariff of $75 \%$.

Our tariff equivalents are computed using a fixed effects methodology which is shown to be preferable to the traditional approach based on normalized residuals of the gravity equation. This means that, with the exception of Transport and Business Services for which figures are comparable, our tariffs are higher.

The results based on actual panel data are quite different from the results obtained for the cross section GTAP data. Those differences are due to the data (reconstructed versus actual) not the methodology (cross section versus panel). It should be noted, therefore, that using partially ' 'reconstructed data' to 
estimate tariff equivalents may bias results. However, the hierarchy of countries within sectors in terms of the protection obtained using the reconstructed data set is fairly reliable, and most divergences are related to developing economies. Therefore we can be fairly confident about the accuracy of the tariff equivalents of protection in services trade proposed here. 


\begin{abstract}
Methodological issues arising from the estimation of tariff equivalents of barriers to services trade are very relevant for policy. These equivalents are used extensively to compute welfare gains and resource reallocations associated with partial liberalization of the sector; any measurement errors will strongly affect the estimated gains. Using the Global Trade Analysis Project (GTAP) database, we rely on socalled quantity based methods to derive tariff equivalents from a gravity equation estimated at sectoral level for 9 services sectors and 65 countries.

We also estimate trade equations for services using cross section data, and improve on the methodology of Park (2002). We investigate whether relying on cross section rather than panel data leads to differences in the estimated equivalents. Finally, we compare the estimations based on reconstructed and actual data. We conclude that although use of partially reconstructed data (such as GTAP) affects the results, the equivalents obtained are good representations of the magnitude of protection for services in the various countries analyzed, although with larger deviations for developing economies.
\end{abstract}

JEL Classification: F13.

Keywords: $\quad$ Market access, tariffs, trade in services 


\section{LE CALCUL D'ÉQuiVALENTS DROITS DE DOUANE DANS LE COMMERCE DE SERVICES}

\section{RÉSUME NON TECHNIQUE}

Les services représentent le secteur le plus important de l'économie, avec 70\% de la valeur ajoutée mondiale et plus de la moitié de l'emploi total. Toutefois, leur part dans les échanges mondiaux reste limitée ( $21 \%$ du commerce mondial en valeur), en partie en raison des niveaux élevés de protection réglementaire des marchés nationaux. Les simulations réalisées avec des Modèles d'Equilibre Général Calculable concluent à des gains importants à la libéralisation des échanges de services pour les économies avancées comme pour les pays en développement. Comme ces estimations sont fondées sur l'utilisation d'équivalents droits de douane de la protection réglementaire des activités de services, la mesure correcte de ces équivalents est une question importante pour la politique économique.

Une première difficulté tient à la nature spécifique des services, comparés aux biens. La proximité entre producteur et consommateur est souvent nécessaire; en raison de leur nature intangible les obstacles aux échanges de services diffèrent de ceux auxquels sont confrontés les échanges de biens. Ces obstacles prennent la forme de quotas, de licences, d'interdiction d'exercer certaines activités pour les étrangers, ou encore d'accès privilégié pour les entreprises nationales. Ainsi, libéraliser les échanges de services signifie-t-il pour un pays une adaptation de ses réglementations. Mais la valeur exacte de l'équivalent droit de douane des réglementations existantes est une question complexe. D'autant que les données sur les réglementations appliquées sont rares et que transformer cette information qualitative en indicateur quantitatif est difficile. Nous nous écartons donc de l'approche dite de l'inventaire utilisée dans la littérature pour construire des indices de restrictivité. Nous nous écartons aussi de l'approche en deux étapes consistant à utiliser l'information sur les barrières auxquels font face les opérateurs étrangers, pour expliquer les taux de marge des firmes dans les pays utilisateurs.

Une approche indirecte est en effet envisageable. Il s'agit de révéler la protection en comparant le commerce de services observés à une norme. On calcule alors le droit de douane équivalents à la protection réglementaire. La distribution des résidus de l'équation de gravité estimée au niveau sectoriel peut être utilisée à cette fin. Une méthode alternative consiste à calculer la protection appliquée par chaque importateur en exploitant les effets fixes importateurs dans une telle équation. Nous adoptons ici cette stratégie et utilisons une méthode d'estimation plus satisfaisante que celle de Park (2002). Nous calculons finalement les droits de douane équivalents dans le commerce transfrontières de services (Modalité 1). Nous documentons les différents biais d'estimation associés à cette approche.

Nous proposons finalement des équivalents droits de douane pour 9 secteurs de services et 65 pays fondés sur les données du consortium Global Trade Analysis Project (GTAP). Il apparaît que les économies avancées sont celles protégeant le moins leur secteurs de services. Les secteurs les plus libéralisés sont le transport avec un équivalent droit de douane moyen de $26 \%$; à l'opposé la construction est le secteur le plus protégé (respectivement 75\%).

Les résultats obtenus sur données de panel réelles diffèrent toutefois de ceux en coupe instantanée exploitant la base du consortium GTAP. Nous montrons que ces différences sont dues aux données (re- 
construites versus réelles) et non à la méthode (coupe versus panel). Ceci souligne que l'utilisation de données partiellement reconstruites pour calculer des équivalents droits de douane peut biaiser les résultats. Toutefois, la hiérarchie des pays au sein des secteurs, en termes de protection, est malgré tout assez fiable et l'essentiel des divergences concerne des pays en développement. Nous pouvons donc être relativement confiants dans la validité des équivalents droits de douane de la protection des services proposés ici.

\section{RÉSUMÉ COURT}

Le calcul d'équivalents droits de douane des obstacles aux échanges de services représente un enjeu important pour la politique économique. Ces équivalents sont largement utilisés pour calculer les gains de bien être et les réallocations de ressources consécutifs à la libéralisation partielle des échanges dans ce secteur. Aussi toute erreur de mesure est-elle de nature à affecter significativement les gains estimés. Nous utilisons la base de données d'échanges de services du Global Trade Analysis Project (GTAP) et nous appuyons sur la méthode dite des quantités, fondée sur une équation de gravité, pour calculer des équivalents droits de douane dans 9 secteurs de services et 65 pays.

Outre le calcul de ces équivalents, nous estimons des équations de commerce international de services en coupe et améliorions la méthodologie de Park (2002). Nous examinons éalement si l'utilisation de données de panel fait une différence importante. Enfin nous confrontrons les résultats d'estimations s'appuyant sur des données partiellement reconstruites (comme celles de GTAP) et sur des données réelles. Nous montrons que si l'utilisation de données partiellement reconstruites affecte les résultats, les équivalents droits de douane ainsi obtenus caractérisent correctement l'ampleur de la protection dans les services dans les différents pays, avec toutefois des écarts plus importants dans le cas des pays en développement.

Classification JEL: F13.

Mots clés: $\quad$ Protection dans les Services, équivalent droits de douane, commerce de services. 


\title{
ESTIMATIONS OF TARIFF EQUIVALENTS FOR THE SERVICES SECTORS
}

\author{
Lionel Fontagné* \\ Amélie Guillin ${ }^{\dagger}$ \\ Cristina Mitaritonna ${ }^{\ddagger}$
}

\section{INTRODUCTION}

Services is the largest sector in the global economy, representing $70 \%$ of world added value and over half of total employment. However, the share of services in total trade is lagging despite having expanded greatly since the 1980s. Services account for $21 \%$ of total international trade (World-Trade-Organization, 2010), and thanks to major technological progress its importance is expected to increase in the future.

There has been a greater willingness in recent years to include services in bilateral as well as multilateral trade agreements. In the multilateral arena, services were not initially included in negotiations. Their inclusion in the Uruguay Round, led to the General Agreement on Trade in Services (GATS) in January 1995. The GATS relates to the multilateral liberalization of 150 different services sectors, distinguishing between four modes of supply, whose relative importance differs among sectors: ${ }^{1}$

- Mode 1 or Cross-border supply (e.g. financial operation).

- Mode 2 or Consumption abroad (tourism).

- Mode 3 or Commercial presence (Foreign Direct Investment - FDI).

- Mode 4 or Presence of natural persons (temporary workers migrations).

As a result of the growing role of services in world trade, economists have started to pay more attention to this field (Francois et al., 2009). Simulations based on Computable General Equilibrium (CGE) modeling point to the large gains associated with the partial liberalization of services. Sizable gains can be expected for the rich economies, but also for developing countries, especially India and China (Francois et al., 2005; Decreux and Fontagné, 2011).

Since these estimates rely on tariff equivalents of protection for services, an accurate measure of the level of protection in services is key to the assessment of the gains from liberalization. However, computing tariff equivalents can be challenging, both theoretically and empirically.

\footnotetext{
*. Paris School of Economics (University of Paris I) and CEPII. lionel.fontagne@ univ-paris1.fr.

$\dagger$. Paris School of Economics (University of Paris I). amelie.guillin@ univ-paris1.fr

‡. CEPII. cristina.mitaritonna@ cepii.fr

1. The 150 sectors are aggregated into macro-categories: business services, communication, construction and engineering, distribution, education, finance, environmental services, tourism, health and other social services, transport and recreational services.
} 
A first problem is related to the specific nature of services compared to goods. Proximity between producer and consumer and the intangible characteristics intrinsic to services produce different impediments to trade in services from those that apply to goods. These impediments include limitations such as quotas, licences, prohibition of some activities for foreigners, and government regulations intended to reduce market access for foreign firms and/or discriminate in favor of domestic firms. Liberalizing trade in services implies changes to national regulation. From a technical and a political economy perspective, reformulating regulations implies much more than simply cutting a tariff.

A second problem is the scarcity of data on actual policies, and the methodological issues raised by the use of qualitative data. Collecting information on domestic regulation, its degree of restrictiveness and its coverage for each sector and importer, is an immense task. If this information is made available through surveys, indices have to be constructed and used as regressors of price cost margins (Dee, 2005; Dihel and Shepherd, 2007; Fontagné and Mitaritonna, 2009). The OECD has embarked on the construction of Services Trade Restrictiveness Indices (STRI), which are a quantitative measure derived from qualitative information. The World Bank has produced the Global Services Policy Restrictiveness Database which is based on the results of a survey of 102 countries and 5 sectors: financial services, telecommunications, retail distribution, transportation and business services (Borchert et al., 2011). Even if the information is available, its treatment is problematic. Survey results have to be summarized in an index that maps regulations on an arbitrary scale of restrictiveness. When available, results for the different modes need to be aggregated using rather arbitrary weights.

This suggest an indirect approach (Park, 2002; Francois et al., 2005; Walsh, 2006), consisting of computing tariff equivalents and assessing protection by comparing actual trade in services against a benchmark. The distribution of the residuals of a gravity equation estimated at sectoral level can be used for this computation. Alternatively, we can compute the average protection applied by each importer from importer fixed effects coefficients. The data can be cross section or panel data. Because of the scarcity of information, the source can be either reconstructed data if the sample is comprehensive, or actual data, but for only a limited number of countries. This approach cumulates the issues related to reliance on gravity estimates, with problems specific to the source data. Our objective is to address these problems systematically and compute ad valorem equivalents (AVEs) for trade in services relying on this indirect approach.

This paper makes two contributions. First, it highlights the potential problems related to estimating tariff equivalents for trade in services from a gravity equation: we provide evidence of the magnitude of the related estimation bias. Second, it provides tariff equivalents for 9 services sectors and 65 countries, which can be used to estimate the welfare effects of liberalization of services trade. Overall, our tariff equivalents are much higher than for goods. For an industrialized country, tariffs typically range between $0 \%$ and $50 \%-60 \%$ depending on the sector. In the construction sector the barriers may be even higher than this and in several developing countries and for certain sectors, tariff equivalents may be above $100 \%$. These measures are sensitive to the elasticity of substitution chosen and accordingly should be considered with some caution. However, the elasticity of substitution has no impact on the hierarchy of coun- 
tries within sectors.

The rest of the paper is organized in five sections. Section 2 presents the theoretical and empirical issues related to the gravity approach and briefly reviews the literature on gravity models applied to services. The data are described in Section 3 and Section 4 discusses the empirical approach. Section 5 presents the results and Section 6 concludes.

\section{QUANTIFYING TRADE BARRIERS IN SERVICES}

Several attempts have been made to quantify barriers to services trade. There is a strand of literature that is based on inventory approaches. In a seminal paper Hoekman (1996) uses a methodology based on a frequency index, which assigns a numerical value to the level of restrictions imposed by each country in a given sector, by mode of supply. ${ }^{2}$ The country's GATS commitment schedule is used as the main source of information on the barriers imposed by countries. An arbitrary tariff equivalent is then attributed to the country demonstrating the most protectionist policy. Other countries' tariff equivalent are calculated according to the level of their commitment relative to the benchmark. Stern (2000) points out that the Hoekman indices are relative indicators not real indices that can be used as tariff equivalents. Mattoo et al. (2001) build openness indices for telecommunications and financial services to analyze the effects on growth of services liberalization. The first index is based on the market structure of the sector (competitive or not), on FDI (allowed or not) and on the presence (or not) of an independent regulator. The other index (the so-called 'financial index') combines information on market structure, capital controls (the Dailami index) and the level of foreign equity. Financial indices ordering shows that liberalized countries are generally the most developed countries. However, for telecommunications the indices show that some developing countries such as El Salvador and Ghana, are quite open. Concerns regarding data reliability and availability using this method as well as Hoekman's are summarized in Chen and Schembri (2002). Gootiiz and Mattoo (2009) compile actual policy restrictiveness in the services sector for 32 developing and transition economies, and 24 OECD countries. The degree of protection is compared to Doha offers and Uruguay round commitments. A synthetic index is calculated by country and sector for the three levels of restrictiveness, but no AVE is proposed.

A second strand of literature examines the barriers to trade in services relying on a two-stage method. The first stage consists of qualitative assessment of the commitments made by importers under the GATS, or of the barriers imposed on exporters of services by destination markets. In the second stage, the same information is used to explain international differences in price-cost margins within sectors. The Australian Productivity Commission (APC) pioneered the estimation of tariff equivalents using the Trade Restrictiveness Indices (TRI) (Dee, 2005). ${ }^{3}$

2. A weight of 1 is attributed to a sector or a mode with no restrictions, 0 if no policy binds and 0.5 if there is any restriction in a sector or in a mode of supply.

3. A set of qualitative data on barriers is used to build quantitative indexes which are used in econometric models to explain economic performance in order to obtain tariff equivalents: controlling for firm-level variables, price-cost margins are regressed on TRI. Note that these indexes are different from Anderson-type TRI based on different methodologies, despite the similar acronym. 
Relying on a weighting methodology, Dihel and Shepherd (2007) apply the same methodology as the APC. They observe that the non-OECD trade restrictiveness indexes are higher than the OECD indexes. The method is extended in Fontagné and Mitaritonna (2009) and applied to the Distribution and Telecoms sectors in emerging countries. Kox and Nordas (2007) examine how domestic regulation affects trade in services under mode 3 (commercial presence), proxied by the stock of FDI.

Finally, there is a strand of literature showing that the level of protection in services can be revealed through an econometric exercise relying on a gravity equation. Since Tinbergen (1962), the gravity equation has been used extensively in the empirics of international trade, because of its remarkably good predictions of bilateral trade flows in goods. Although it was criticized initially for its lack of theoretical foundations, the gravity equation can be derived from various formal trade models under a wide range of modeling assumptions. ${ }^{4}$ Essentially a gravity equation is an expenditure equation with a market clearing condition imposed. Two price terms, labeled as multilateral resistance terms following Anderson and van Wincoop (2003), appear into the equation. These terms are quite complex, and not directly observable because they include missing data, for instance, number of the varieties consumed or producer price of each variety. The problem here is that the omitted terms are correlated with the trade cost term because they are a function of the bilateral trade costs. This correlation mean that the estimates of the trade cost determinants are biased. The main value added by Anderson and van Wincoop (2003) is derivation of a practical way of using the full expenditure system to estimate key parameters on cross-section data and to show that including country specific fixed effects yields the same results. With panel data, however, the problem is more severe. If we assume that omitted terms vary over time, including time-invariant country dummies removes the cross-section bias, not the time series dimension. Thus, a good solution is to include time-varying country dummies. The alternative of a time-varying pair dummy is rarely useful, since most gravity models are aimed at identifying bilateral trade barriers which would be impossible to estimate since they are already captured by pair fixed effects.

In contrast to work demonstrating the effectiveness of the gravity equation applied to trade in goods, the literature on application of the gravity model to services trade, pioneered by Francois (1993), is limited. However, it has increased since 2000 (Mirza and Nicoletti, 2004; Kimura and Lee, 2006; Francois et al., 2009), due mainly to improved data quality although the availability of information on services trade still lags behind information on trade in goods. Francois et al. (2005) rely on sector-specific gravity equations estimated on data from the GTAP and show that, to estimate trade barriers, the standard specification is significant even for trade in services. Kimura and Lee (2006) confirm that Gross Domestic Product (GDP), distance, remoteness, adjacency, Regional Trade Agreement (RTA), economic freedom index and com-

4. For examples of the theoretical foundation of the gravity equation see, e.g., Anderson (1979), Helpman and Krugman (1985), Bergstrand (1990), Deardorff (1998), Feenstra (2002), Feenstra (2004), Anderson and van Wincoop (2003), Helpman et al. (2007), Melitz and Ottaviano (2008). The development of the theoretical models has been useful for explaining why, despite the goodness of fits, results from estimations of bilateral trade costs variables may be severely biased. Baldwin and Taglioni (2006) provide for a minimalist derivation of the gravity equation furnishing estimates of the size of the biases commonly found in the literature, taking currency union as an example. 
mon language are significant and robust determinants of bilateral trade in services (imports and exports). Walsh (2006) estimates a specific gravity equation for four sectors (transport, government, other commercial services, and travel). The explanatory variables are per capita GDP, population, distance, adjacency, common language and a dummy for European Union membership. All the variables are statistically significant and have the expected impact on the value of bilateral trade. However, interpretation of the results for distance should be cautious. ${ }^{5}$

For the computation of tariff equivalents based on the gravity equation, the approach proposed by Park (2002) and using the residuals of this equation is generally supported by applied models addressing the economic impact of liberalization of trade in services. The gravity equation used is based on Deardorff (1998) and considers the most commonly used explanatory variables in gravity equation used such as GDP, distance and language. We elaborate on Park's work later in the paper. Note, however, that Park (2002) departs from Anderson and van Wincoop (2003) regarding how prices are tackled. Park's results for the estimation of tariff barriers for seven different sectors are very different from Hoekman (1996). From an elasticity of substitution of 4.67, the tariff equivalents computed by Francois et al. (2005) are based on the actual to predicted trade ratio. With this method, India is the least opened country while Sub-Saharan Africa and Netherlands have 0\% trade cost equivalents for the four categories of services considered. Using a similar method to Park's, but with an elasticity of substitution of 1.95, Walsh (2006) finds average tariff equivalents ranging from $0 \%$ (Japan, Norway and Belgium) to $125 \%$ (Indonesia). Francois et al. (2009) rely on a large sample of importing countries (39 or 49 depending on the sector) and estimate the elasticity of trade in services to the presence of Non Tariff Barriers (NTBs) using a probit selection estimator (up to $40 \%$ of their bilateral observations are zeros for business and information and computer and telecom services). They apply this estimation to 6 service sectors, using data for 2004-2006. They interact the OECD's openness index for operations of multinational enterprises (FDI restriction index) with dummies for regional trade agreements. The computed trade elasticities range from -0.5 (communications) to -8.7 (personal and cultural recreation). For business and Information and Communication Technologies (ICT), Insurance, Finance and Construction, the range is 2.0 to -4.2 . If we assume that trade costs vary in proportion to the OECD openness index, what is obtained can be considered to be import price elasticities.

It can be seen that potentially there are numerous methodological issues that can arise in using the gravity method. First, the distribution of the residuals of the estimated equation is sensitive to specification and omitted variables problems which affect the estimation of tariff equivalents. Hence, it might be preferable to rely on a strategy based on country fixed effects. Second, it is necessary to make an assumption about the elasticity of substitution to transform the parameter estimate into an AVE. The value of the equivalents is highly sensitive to this assumption. Third, since sectoral and bilateral data on trade in services is scarce, many papers rely on reconstructed data, based on econometrics, which a priori is questionable.

In order to highlight the various problems associated with the gravity method, in this paper we estimate tariff equivalents for the service sectors, focusing on cross border trade in services (Mode 1). We rely on so-called quantity based methods. Initially we estimate services trade

5. In the case of services, compared to goods, distance has a different meaning, which is due to the intangible nature of what is being traded. This variable may be capturing informational imperfections in particular. 
equations on cross section data. We use the most recent version of the GTAP database provided by the Netherlands Bureau of Economic Analysis (CPB thereafter) for 2004. Using the same source data as Park (2002), but for a more recent cross section, we prefer a methodology based on country fixed effects. We provide estimates of trade barriers for a larger set of countries (65 vs 51) and sectors. The robustness of these estimations is systematically challenged by addressing the methodological issues referred to above.

\section{DATA}

We draw on a relative small set of data sources. The main source of data used in the first stage of this paper is the GTAP database which provides bilateral trade in services for 14 services sectors for the year 2004: Construction (cns), Communication (cmn), Trade (trd), Finance (ofi), Other services (osg) comprising education, health, defense and public administration, Business (obs), Air transport (atp), Water transport (wtp), Other transport (otp), Insurance (irs), Recreational services (ros) and Dwellings (dwe), Water (wtr) and Energy (ely). ${ }^{6}$ In line with Park (2002) we consider the same seven services sectors originally studied: cmn, cns, obs, trn, trd, ofi, osg. Trn, which is Transport, includes the three transport sectors (atp, wtp and otp). However, in the alternative estimation strategy we add two more sectors: isr and wtp.

The number of countries varies according to the different versions of the GTAP database. The 7.4 release includes 82 regions, but fewer individual countries, ${ }^{7}$ which allows a large representation of both developed and developing countries. Unfortunately not all are single countries, some are regions made up of Least Developed Countries and Developing Countries. ${ }^{8}$ We decided these amalgamations, as both importers and exporters, due to the problem of using control variables for non-single countries. When deleting a region as an exporter we were careful to retain single countries as importers if we had $70 \%$ of their bilateral trade in the remaining data.

There are IMF data on GDP and on Producer Price Indexes (or Wholesale Price Indexes for some countries) for the year 2004. Population data are from the World Bank (World Development Indicators - WDI). Distances and all remaining control variables are from the CEPII database. ${ }^{9}$ For some countries, namely Bostwana, Malawi, Morocco, Mozambique, Tanzania, Uganda, Zambia and Zimbabwe, we do not have data on Producer Price Indexes and, therefore, cannot estimate tariff equivalents for them when prices are used as regressors in the gravity estimation.

The reliability of the data is fundamental for our analysis; van Leeuwen and Lejour (2008) address the quality of GTAP and OECD data. They compute reliability indices for 1999-2003 and

6. We rely on release 7.4 of the database. See https://www.gtap.agecon.purdue.edu/

7. Park relies on version 5, which includes 52 countries, for his estimation for 1997. The presence in Park's work of tariff equivalents for Botswana, Uganda, Mozambique, Tanzania, Malawi and the Zambia is puzzling, since the producer price indexes for these countries are not available in IMF data for 1997.

8. This applies particularly to African countries. Israel is not documented individually in GTAP.

9. The database is freely available on the CEPII Web site http://www.cepii.fr . 
show that reliability is not uniform across sectors or countries. ${ }^{10}$ In a sample of 29 countries, they find that less than half of them countries have good indices. In addition to reliability, how the data were collected or constructed also influences the exercise, as we show below.

An alternative is to estimate a gravity equation using panel data. In this case the regression analysis uses OECD data for the period 2002-2006, in preference to GTAP data mainly because it offers better country coverage and annual frequency. There are somewhat more observations for Total services (code 200) than for the three disaggregated categories considered: ${ }^{11}$ Transport (code 205), Communication (code 245) and Construction (code 249). ${ }^{12}$ An additional advantage to using these kinds of data emerges during this exercise. ${ }^{13}$.

We employ the exports reported by OECD countries. Countries of interest, such as India and China, enter the OECD data as partners through their trade with reporting countries. OECD import data are utilized to complete the dataset. This means that emerging economies appear as exporters, but only to OECD markets. Trade flows between two non-reporting countries remain unavailable. However, we are able to account for more than $89 \%$ of total services exports. ${ }^{14}$

\section{Methodology}

There are two points to note: we can use cross section or panel data, and these data can be actual data or reconstructed data. In the case of reconstructed data, a wider range of countries is available, but an econometric model is required for the reconstruction.

We start with the traditional cross-section approach, using GTAP dataset which relies on reconstructed data. We extend the gravity equation proposed in Park (2002) in order to introduce omitted variables. We tackle the misspecification of this equation concerning prices. We favor a fixed effect methodology over the use of residuals. In a second step, we replicate the exercise using (actual) panel data from the OECD. We compare panel and cross section estimates using the same (actual) data source. We identify discrepancies associated with the use of reconstructed data, such as GTAP; cross section and panel estimations are comparable. The last step involves calculation of tariff equivalents either, as is traditional, based on the estimated residuals, or alternatively the importer fixed effect coefficients.

\subsection{Gravity equations estimated on cross-sectional reconstructed data}

We first estimate a cross section gravity equation relying on partially reconstructed data. In the GTAP database on trade in services, based on OECD data, the gaps for missing data are filled and the data are reconciled. ${ }^{15}$ This raises two issues: we rely on a very specific set of data for

10. It is more difficult to obtain good data on the recreational sector than for the travel sector.

11. We decided to consider only the sectors for which mirror data covered at least $90 \%$ of the value of the declaration of the origin country.

12. The codes correspond to the nomenclature employed by the Extended Balance of Payments Services.

13. A similar dataset was constructed by Francois et al. (2009), using data on FDI (IIDE TSD dataset.)

14. We use Balance of Payments data to calculate the coverage of our data in the different sectors considered at the multilateral level.

15. The method is explained in van Leeuwen and Lejour (2008). 
trade in services, that is, the GTAP data set, and perform a cross-section estimate. First, we replicate Park (2002) using the last release of the data, then we add some controls, and finally we adopt a better suited econometric specification. This allows us to propose tariff equivalents.

The econometric model is as follows:

$$
\ln \left(x_{i j}\right)=c+\alpha_{1} \ln \left(y_{i}\right)+\alpha_{2} \ln \left(y_{j}\right)+\alpha_{3} \ln \left(P_{j}\right)+\alpha_{4} \ln \left(P_{i}\right)+\alpha_{5} \ln \left(d_{i s t} t_{i j}\right)+\sum \alpha_{i j} D_{i j}+\varepsilon_{i j}
$$

where $x_{i j}$ is the export of services under Mode 1 from country $i$ to country $j, y_{i}$ is the exporter's GDP, $y_{j}$ is the the importer's GDP, $P_{j}$ is the overall importer's Production Price Index and $P_{i}$ is the overall exporters' Production Price Index,${ }^{16}$ dist $_{i} j$ is the distance between the two countries and $D$ is a vector of the dummies, which, in the original work includes common language, border and dummies for the partner countries being in Asia or Latin America or both. ${ }^{17}$

Using equation 1 we test three different specifications of Model 1:

- Model 1.1: Firstly we try to replicate as closely as possible, Park's specification, and consider the same group of countries and sectors, and the same regressors. The only difference is the base year for the regression, which is 1997 in Park and 2004 in our case.

- Model 1.2: Some variables of interest are omitted from the previous specification and we add some regressors, notably dummies for partner countries being party or not to Regional Trade Agreements (RTA), such as NAFTA, ASEAN or ANZCERTA, or being both EU member states. We also include variables for common ethnic language and colony.

- Model 1.3: The estimation is basically the same as in Model 1.2, but with a larger sample of countries (65 vs 51).

In Park (2002), the estimations with model 1 are aimed at obtaining residuals of the estimated equation from which to derive tariff equivalents. Accordingly, the precision of the tariff equivalents is dependent on the quality of the estimation and the associated residuals. This raises two issues. First the prices considered in the regressions are not theoretically founded. ${ }^{18}$ Second, unobserved characteristics may be correlated with the residuals, leading to biased estimates.

Against this background we prefer to rely on a different strategy based on country fixed effects (Model 2). In a cross sectional dimension, fixed effects yield consistent estimations. Since our interest is in measuring the 'average protection' of the importer, proxied by the importer fixed effects, it is important at least to isolate the GDP importer effect, so that the coefficient on the importer fixed effect contains information only on protection. We chose to constrain the coefficient of the importer GDP to $0.8 .{ }^{19}$ Model 2 is estimated as:

$$
\ln \left(x_{i j}\right)=c+0.8 \ln \left(y_{j}\right)+\alpha_{1} \ln \left(d i s t_{i j}\right)+\sum_{i} \gamma_{i} I_{i}+\sum_{j} \gamma_{j} I_{j}+\sum \alpha_{i j} D_{i j}+\varepsilon_{i j}
$$

16. Data on sectoral PPI are not available.

17. The original work also includes the dummy Sub Saharan which we dropped because of lack of data on the group of countries in that region.

18. The latter, however, are not observable, as discussed in 2.

19. Feenstra (2002) suggests this coefficient should be fixed at unity, but it is generally accepted in the literature that the openness of countries is not constant: smaller countries are more open than larger ones. 
where $I$ is a country specific dummy, for the importer and the exporter, which controls for a country's unobserved characteristics (not just price index but also any additional country characteristics that affect the propensity to import(export), such as the share of services in the structure of the economy). We do not control for unobserved characteristics of pairs of countries, which is why we again include bilateral variables such as distance and dummies $D_{i j}$ for common language and RTAs. Using fixed effects, the econometric model has very good explanatory power: the $R^{2}$ ranges from 0.93 to 0.99 . In this case the error term is just noise.

Similar to Model 1, for this specification we also propose three alternatives of Model 2:

- Model 2.1: we consider the same regressors as in Model 1.1, replacing importer and exporter variables with country fixed effects except for the importer's GDP.

- Model 2.2: we add some more regressors, as in Model 1.2.

- Model 2.3: we use a bigger sample of countries (65 against 51).

The use of $G D P_{i}$ and $G D P_{j}$ needs some justification since the theoretical models suggest using production for the exporter and the expenditure function for the importer (which is quite close to the concept of consumption). There are several arguments supporting the use of GDP. First, consumption and production already encompass bilateral trade, which is the dependent variable. Second, in order to obtain measures of protection, we need to use regressors that do not rely on protection, which does not apply to production; a country that produces nothing in a particular sector, will provide fewer barriers for this sector (and vice-versa). Finally, the base year for GTAP Input-Output data vary for the countries considered in the regression, and some are quite old ${ }^{20}$ reflecting country characteristics that are different from the current economic situation.

Overall, we consider that the best estimations come from the importer and exporter fixed effects econometric model. As the estimation of tariff equivalents is substantially invariant across different specifications of Model 2, Table 10 in Appendix 8.2 present the results only for Model 2.3.

\subsection{Gravity equations estimated using actual panel data}

There are obvious limitations to relying on deviations from a cross sectional equation to compute AVEs of protection in services. These are even more pronounced if the data are partially reconstructed. The alternatives is to use panel data, which are actual data. We fit the gravity model to 2002-2006 OECD data to check the accuracy of our previous results. In adding a time dimension, the model estimated becomes Model 3:

$\ln \left(x_{i j t}\right)=c+0.8 \ln \left(y_{j t}\right)+\alpha_{1} \ln \left(d_{i s t_{i j}}\right)+\sum_{i t} \gamma_{i t} I_{i t}+\sum_{j} \gamma_{j} I_{j}+\sum{ }_{t} \gamma_{t} I_{t}+\sum \alpha_{i j} D_{i j}+\varepsilon_{i j t}$

The specification is very closed to model 2 . However since we are working with panel data, we include in Model 3 country-and-time fixed effects, which account for multilateral resistance

20. See Table 11 in Appendix. 
terms varying over time. ${ }^{21}$ For the importer fixed effect, we include only a country dummy, given the small time variation considered (2002-2006). ${ }^{22}$ Here again, because we use the importer fixed effect to measure the average protection applied by the importer, we isolate the variable GDP importer, constraining it to 0.8 .

To control for the time invariant bilateral determinants of trade we add the usual regressors: bilateral distance and dummies, $D_{i j}$, for common border, common language or countries in a colonial relationship or countries belonging to a FTA. ${ }^{23}$ Finally we include a full set of year dummies, $I_{t}$, to allow for time varying means of the error terms.

\subsection{Derivation of tariff equivalents}

The next step involves the calculation of tariff equivalents. Recall that in addition to the methodological choices made, we need to decide on the data: whether to use partially reconstructed data for a larger set of countries, or original bilateral and sectoral data.

Whatever data are used, there are alternative ways to compute the average protection applied by each importer: either using estimated residuals (Park (2002)), or using importer fixed effect coefficients. There are pros and cons to both methods. Residuals contain information on other aspects than protection and their magnitude and goodness of fit depend largely on the fit of the equation performed; the importer fixed effects coefficient also captures more than just protection. We need to examine the underlying theory in more depth to understand the assumptions involved in reliance on the canonical gravity equation derived by Anderson and van Wincoop (2003) in order to compute the revealed trade barriers of a country $j$.

Exports from country $i$ to country $j$ accounting for a share $s_{j}$ of world income end up as a simple function of the product of their GDP and of trade costs. ${ }^{24}$ Taking $Y$ as GDP (subscript $w$ for world), $\tau$ as trade costs and $\sigma$ as the elasticity of substitution, we obtain the following equation, where $P_{j}$ is the price index in $j$ :

$$
X_{i j}=\frac{Y_{i} Y_{j}}{Y_{w}}\left(\frac{\tau_{i j}}{\Pi_{i} P_{j}}\right)^{1-\sigma}
$$

where

$$
\Pi_{i} \equiv\left(\sum_{j} s_{j}\left(\tau_{i j} / P_{j}\right)^{1-\sigma}\right)^{1 /(1-\sigma)}
$$

How the estimated equations fit is straightforward. In Model (1), $Y_{i}$ and $Y_{j}$ are observed; producer price indices proxy $\Pi_{i}$ and $P_{j}$; and $Y_{w}$ is in the constant. In Model (2), $Y_{j}$ is observed,

21. These resistance terms are truly theoretically funded.

22. We assume that over such a short period importer average protection remains unchanged.

23. Here we consider as RTA only NAFTA, Europe and ANZCERTA.

24. In the case of services under Mode I there are no transport costs and trade costs are simply the revealed protection exerted by the presence of regulations. 
$Y_{i} \Pi_{i}^{(\sigma-1)}$ is captured by the exporter fixed effect and $P_{j}^{(\sigma-1)} t_{i j}^{(1-\sigma)}$ by the importer fixed effect and $Y_{w}$ is in the constant. ${ }^{25}$

Anderson and van Wincoop (2003) discuss whether equilibria associated with asymmetric and symmetric trade barriers can be distinguished empirically and make assumptions about symmetry in order to obtain $\Pi_{i}=P_{i}$. Here we stick to the asymmetric case. We must now assume that the regulation on a service sector in $j$ has the same impact on the exports of all affected partners $i$, hence $\tau_{i j}=\tau_{j}$ for all $i$, and that the impact on $\Pi_{i}$ of changes in $\tau_{j}$ is small enough to be ignored, because of the small size of $s_{j}$.

As regulations are not directly observed we need to compare actual trade with a theoretical situation (superscript free) excluding any trade costs associated with such regulations in $j$. After simplification, we can compute the theoretical ratio of $x_{i j}$ over $x_{i j}^{\text {free }}$, as $\alpha_{j}^{\sigma-1} \tau_{i j}^{1-\sigma}$, with $\alpha \equiv P_{j} / P_{j}^{\text {free }} .{ }^{26}$ This ratio is a deviation of $j$ 's actual imports of services compared from its free trade imports, which is due to the presence of regulations, with the exponented price term in front of $\tau_{i j}^{1-\sigma}$ small enough to be neglected.

Can we use this information on $\tau$ directly to infer the actual level of protection? The answer is no; another step is needed. As correctly noticed by Park (2002), the theoretical value of $x_{j}^{\text {free }}$ cannot be observed. Thus we need to define a benchmark country, supposed to be the free trader in the sample. All calculations must be relative to this benchmark and we need to normalize the above ratio of actual to predicted trade (free trade is no longer observable) for country $j$ by the same ratio as computed for the benchmark, the benchmark being the country with the highest positive difference between actual and predicted average import values. Under the above assumptions and after summation over $j$ 's partners, the log of this double ratio becomes the difference in the logs, as follows, where $X_{j}$ is the sum of $j$ actual imports from all its partners:

$$
\ln \left(1+t_{j}\right)^{1-\sigma}=\ln \frac{X_{j}}{X_{j}^{\text {predicted }}}-\ln \frac{X_{\text {benchmark }}}{X_{\text {benchmark }}^{\text {predicted }}}
$$

Using the second (fixed effect) methodology Equation 6 becomes:

$$
\ln \left(1+t_{j}\right)^{1-\sigma}=F e \gamma_{j}-F e \gamma_{b e n c h m a r k}
$$

where the benchmark now is the country with the highest importer fixed effect coefficient. This second methodology is the one we use here.

From equation 6 or 7 we can estimate $\ln \left(1+t_{j}\right)^{1-\sigma}$. Finally, to compute $t$, the tariff equivalent, we need to make another crucial assumption about the elasticity of substitution. As in Park

25. $\tau_{i} j$ is indeed the power of the AVE.

26. Recall that $\tau=1$ in absence of trade barriers. 
(2002) and for sake of comparison, we use the value of 5.6 for the elasticity of substitution in each sector. To the best of our knowledge the literature does not provide a rigorous measure for $\sigma$ in the services sectors. However, the large differences across services sectors in the import price elasticities obtained in Francois et al. (2009) suggests that elasticity of substitution may also vary considerably. This is clearly a limitation of our method. However, using different ad-hoc measures for the elasticity of substitution, would serve only to modify the magnitude of the AVE without changing the ranking among countries within sectors, which ultimately is the most reliable information.

\section{ESTIMATION RESULTS}

\subsection{Beyond Park's specification: regression results on (cross section) reconstructed data}

Table 5 in the Appendix presents the basic results for the exact replication of Park's methodology, namely Model 1.1. Accordingly we consider the Park's 7 service sectors. On the whole, our model performs relatively well with a $R^{2}$ between 0.65 and 0.90 . The standard explanatory variables exhibit signs in line with the gravity literature. Trade in services rises with the size of the exporters and importers (proxied here by GDP) and decreases with distance (ldist). On average, a common language appears to have a positive effect on trade while, belonging to the same zone, such as ASEAN (bilsa) or Latin America (bilac), does not favor trade between countries. Although rather counterintuitive, this result demonstrates that trade in services mainly concerns developed country pairs or pairs with at least one developed country partner. The exception is the business services sector (obs) in Asia (well documented in the literature), which shows a positive impact of free-trade agreement on trade.

The significance of two explanatory variables, namely distance and common language, strongly decrease if we amend Model 1.1. For distance, in particular, when the other control variables are included (Model 1.2), or when nation fixed effects replace importer and exporter specific determinants (see Model 2.1, Model 2.2 and Model 2.3), the coefficient becomes insignificant, except for the construction sector (cns). Recall that distance is more strongly related to informational imperfections than to transport costs in the case of services. ${ }^{27}$

We prefer to rely on a fixed effect approach, such as Model 2.3. The results are presented in Table 1 for nine sectors and for 2004. The fit of the equation is good, but most controls related to other gravity-like variables or regional agreements are generally not significant, a result that would be different for trade in goods.

27. Results are provided in Appendix 7, in the following tables: Table 8 for Model 1.2, Table 9 for Model 1.3; Table 10 for Model 2.1; Table 11 for Model 2.2 and Table 12 for Model 2.3. 


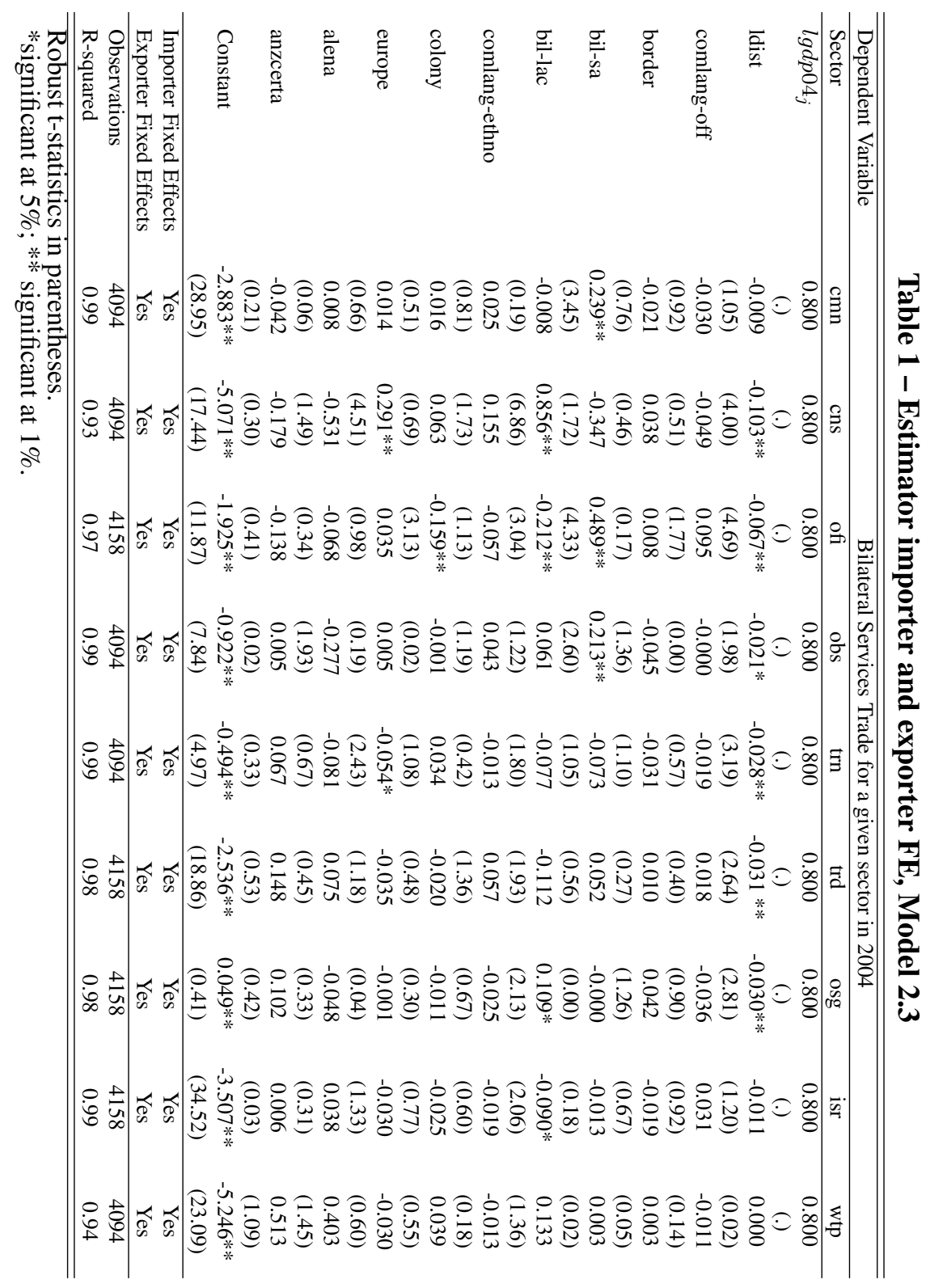




\subsection{Considering the zero flows}

An issue that has been addressed extensively in the literature on gravity estimates of trade flows, is zero flows. Zero flows are particularly relevant in the case of services because several countries do not export certain categories of services to certain destinations. However, in our case the zero flows issue is less challenging: first we use reconstructed data and thus missing data are filled; second true zeros are less important because the sectors are fairly aggregated (we have 4,094 observations rather than 4,158 for the following sectors: communications, construction, other business services, transport, water transport). We estimated the equation again using the negative binomial. The regression results in Table 2 show that our method is not sensitive to the presence of zeros. Results are stable and the estimated tariff equivalents are similar with or without controlling for zeros (see Figure 3 in the next section). 


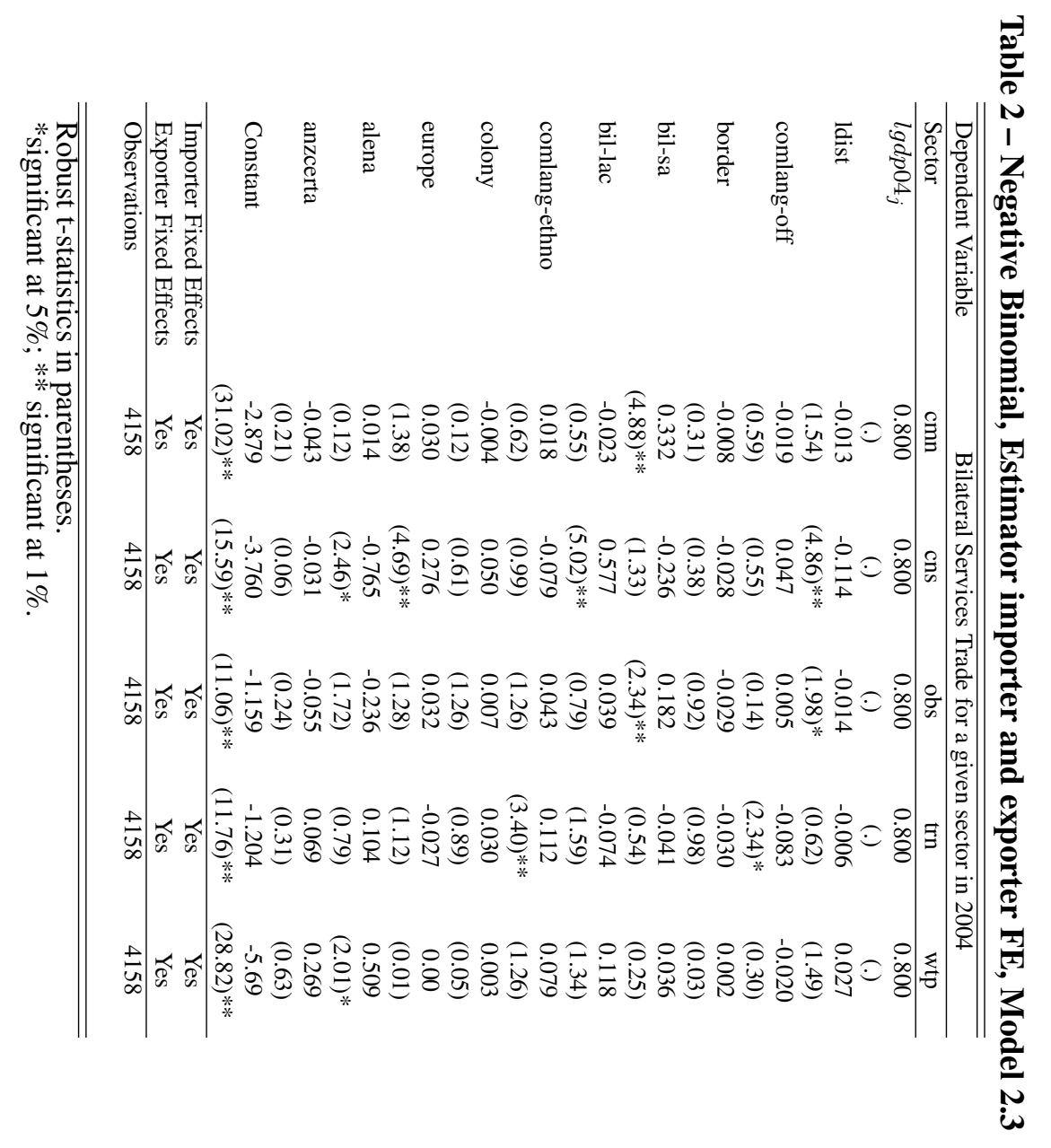




\subsection{Regression results from estimations on actual data}

We performed panel data estimations for the period 2002-2006, using OECD data, to check the sensitivity of computed AVEs to the presence of reconstructed data in GTAP. Table 3 reports the results for Total services (200) and for three other subcategories for which the data are available: Transport (205), Communication (245) and Construction (249). The comparison with previous studies that employ panel data is not straightforward. Firstly samples vary across studies in terms of country, time and sectors covered. Secondly, to the best of our knowledge, there is only one study that estimates trade equations in services including time-varying importer and exporter fixed effects (Head et al., 2007).

\section{Table 3 - Panel estimation with FE (Model 3) using panel OECD data}

\begin{tabular}{|c|c|c|c|c|}
\hline \multirow{2}{*}{$\begin{array}{l}\text { Dependent Variable } \\
\text { Sector }\end{array}$} & \multicolumn{4}{|c|}{ Bilateral Services Trade (2002-2006) } \\
\hline & ALL & Trn & $\mathrm{Cmn}$ & Cns \\
\hline \multirow{2}{*}{$l g d p_{j t}$} & 0.800 & 0.800 & 0.800 & 0.800 \\
\hline & (.) & (.) & $()$. & (.) \\
\hline \multirow[t]{2}{*}{ ldist } & -0.99 & -0.97 & -1.17 & -1.12 \\
\hline & $(0.02)^{* * *}$ & $(0.02) * * *$ & $(0.04)^{* * *}$ & $(0.07)^{* * *}$ \\
\hline \multirow[t]{2}{*}{ cmlng-off } & 0.48 & 0.254 & 0.15 & -0.597 \\
\hline & $(0.04)^{* * *}$ & $(0.05)^{* * *}$ & $(0.09)$ & $(0.18)^{* * *}$ \\
\hline \multirow[t]{2}{*}{ border } & 0.43 & 0.25 & 0.18 & -0.31 \\
\hline & $(0.06)^{* * *}$ & $(0.07)^{* * *}$ & $(0.12)$ & $(0.18)^{*}$ \\
\hline \multirow[t]{2}{*}{ colony } & 1.16 & 0.74 & -0.71 & 0.34 \\
\hline & $(0.04)^{* * *}$ & $(0.06)^{* * *}$ & $(0.09) * * *$ & $(0.17)^{*}$ \\
\hline \multirow[t]{2}{*}{ alena } & -0.29 & -0.56 & 0 & 0 \\
\hline & $(0.27)$ & $(0.23)^{* *}$ & $(0)$ & $(0)$ \\
\hline \multirow[t]{2}{*}{ europe } & 0.325 & 0.26 & -0.14 & 0.14 \\
\hline & $(0.04)^{* * *}$ & $(0.06)^{* * *}$ & (0.13) & $(0.217)$ \\
\hline \multirow[t]{2}{*}{ anzcerta } & 0.59 & 0.64 & 0.73 & -0.477 \\
\hline & $(0.11)^{* * *}$ & $(0.16)^{* * *}$ & $(0.22)^{* * *}$ & $(0.66)$ \\
\hline \multirow[t]{2}{*}{ Constant } & 22.42 & 19.27 & 18.73 & 17.48 \\
\hline & $(0.23) * * *$ & $(0.27)^{* * *}$ & $(1.05)^{* * *}$ & $(0.77)^{* * *}$ \\
\hline Importer FE & Yes & Yes & Yes & Yes \\
\hline Exporter-Year FE & Yes & Yes & Yes & Yes \\
\hline Year FE & Yes & Yes & Yes & Yes \\
\hline Obs & 16249 & 7984 & 3087 & 2363 \\
\hline R-squared & 0.82 & 0.73 & 0.79 & 0.72 \\
\hline
\end{tabular}

Robust t-statistics in parentheses.

*significant at $10 \%$; **significant at 5\%; *** significant at $1 \%$.

Note: Correspondence of sectoral acronyms: trn: transport $-\mathrm{cmn}$ : communications - cns: constructions

The picture that emerges from Table 3 is that the gravity equation in panel, even using the more sophisticated fixed effects specifications, is as effective for explaining services trade as trade in goods. We found strong distance effects as in Head et al. (2007) which contrasts with the results obtained from the fixed effects specifications on cross section data, namely Model 2.1, Model 2.2 and Model 2.3, where most of the controls related to gravity-like variables or regional agreements other than distance, are generally not significant. However, the distance variable might have a different 'meaning' in the services sector. In the case of services distance is also a proxy for omitted variables which are important determinants of trade in services (e.g. cultural and institutional variables). 


\section{TARIFF EQUIVALENTS}

The main objective of this paper is estimation of tariff equivalents. In this section we try to assess the reliability of the average protection obtained using the GTAP data with the fixed effect methodology, compared to the full set of estimations from the previous sections. The GTAP is the largest available source of data on trade in services, both in terms of sectors and countries. Appendix 8.2 reports the AVEs by importing country for the nine services sectors using Model 2.3. In a later stage we examine whether alternative strategies lead to different results.

Before commenting on the results note that benchmark countries are either developed countries or emerging economies such as Hong Kong and Singapore, and (with some exceptions) are the same across different specifications (Table 4).

Table 4 - Benchmark countries, cross section regressions using GTAP data

\begin{tabular}{rrrrrrr}
\hline \hline Sector & Model 1.1 & Model 1.2 & Model 1.3 & Model 2.1 & Model 2.2 & Model 2.3 \\
\hline cmn & HKG & PHL & PHL & HKG & HKG & HKG \\
cns & HKG & PHL & KAZ & HKG & HKG & HKG \\
ofi & BEL & BEL & BEL & BEL & BEL & BEL \\
obs & MYS & MYS & MYS & AUT & AUT & AUT \\
trn & ARG & ARG & ARG & SGP & SGP & SGP \\
trd & IRL & IRL & IRL & IRL & IRL & IRL \\
osg & HKG & HKG & HKG & HKG & HKG & HKG \\
isr & & & & MEX & MEX & MEX \\
wtp & & & & GRC & GRC & GRC \\
\hline \hline
\end{tabular}

We turn next to the level of protection in the different categories of services, estimated on cross section regressions using the GTAP dataset for the year 2004. Figure 1 allows comparison between the results estimated using the methodology proposed in Park (2002) (plotted on the vertical axis) and those estimated using fixed effects (horizontal axis), at sectoral level, for a common sample of countries and sectors. In both cases, we use the same 2004 GTAP database and show averages by sector over the whole sample. Note that Park (2002) imposes a constraint on importing countries to obtain tariff equivalents, assuming that total residuals are zero. The issue here is that, to obtain the average protection for a given importer, we need to sum all the countries exporting to that market, which will be different for each importer. Imposing such a constraint on the residuals means eliminating the export composition effect, which is questionable. In Figure 1, we rely on the fixed effects strategy, which controls for the export composition effect.

First, we notice that tariff equivalents based on Model 2.3 are generally higher, except for Other services (osg), where figures are comparable. This illustrates that misspecification of the model can cause systematic bias, and underestimate actual trade barriers. Two similarities are evident: the most liberalized sector remains Transport (trn) with an average protection of 26\%, and the most protected is Construction (cns), with an average tariff of $75 \%$. The high barriers for Construction is to be expected since, as Park underlines, in general foreign firms "are not permitted to bid for procurement contracts". 
Figure 1 - AVEs as estimated using GTAP data (percent).

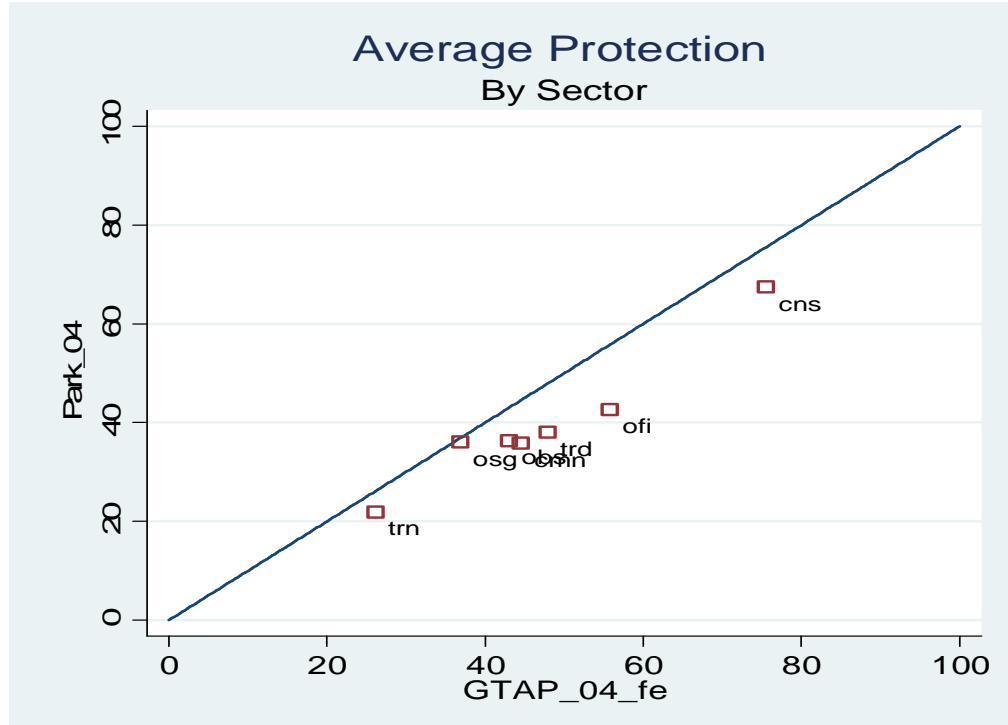

Figure 2 plots the normalized sector values of protection, by country and for each of the seven GTAP sectors. ${ }^{28}$ The difference between the two methodologies is evident in all three sectors of Construction (cns), Other business services (obs) and Trade (trd), and is particularly important for developing countries.

The horizontal axis in Figure 3 plots the tariff equivalents computed using the GTAP database without controlling for zeros and the vertical axis plots tariff equivalents controlling for zeros with a negative binomial estimation. With some exceptions (Business services), our method is shown to be not sensitive to this issue.

The comparison of tariff equivalents obtained using OECD data points to some sources of difference. Because we use the model predictions to derive tariff equivalents, we need to isolate the differences stemming from the data (actual or reconstructed data) and from the methodology (cross section versus panel data).

To disentangle these two effects, we first compare the results obtained with the GTAP dataset with those obtained using panel OECD data (see Figure ??) and then, for the same data source (OECD), compare the results obtained from cross section versus panel estimations (see Figure ??).

28. We do not include wtp and isr sectors, as they are not covered in Park's paper. In order to compare the two methodologies across sector and countries, we standardized the distribution of the estimated protections, i.e. we subtracted the population mean from each country's tariff equivalent and divided the difference by the standard deviation. 
Figure 2 - AVEs as estimated using GTAP data. By sector and countries.
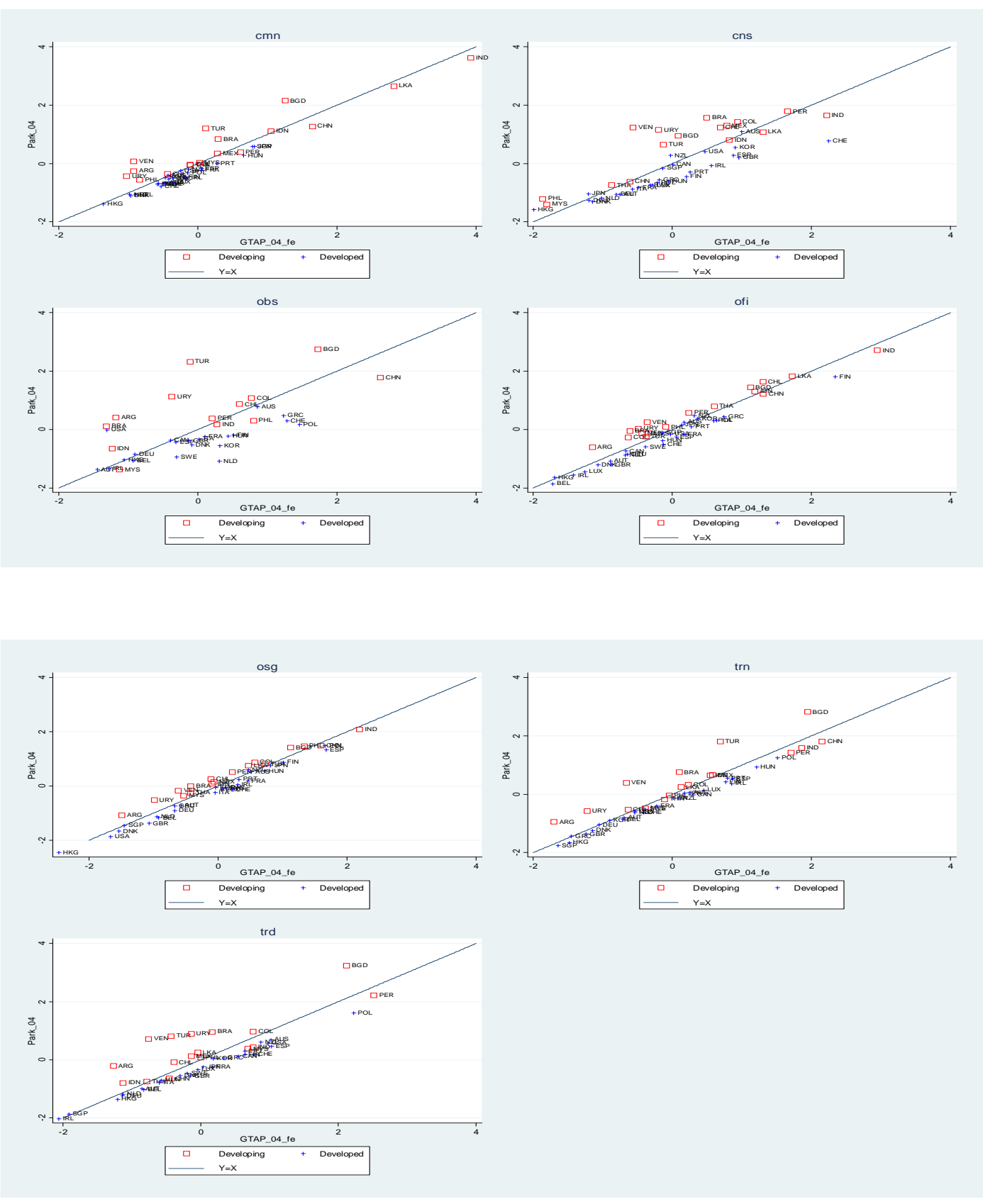
Although the comparison includes only two sectors, communication (cmm) and transport (trn), ${ }^{29}$ Figure ?? shows that the discrepancies due to the methodology used are minimal. At the same time, the tariff barriers estimated on panel estimations using OECD data are different from those obtained in cross section using GTAP data (see Figure ??). This confirms that the main issue is reconstructed data, which relates mostly to emerging economies.

29. We do not include Construction (cns) because when using OECD data for many countries the importer fixed effect coefficient was not significant 

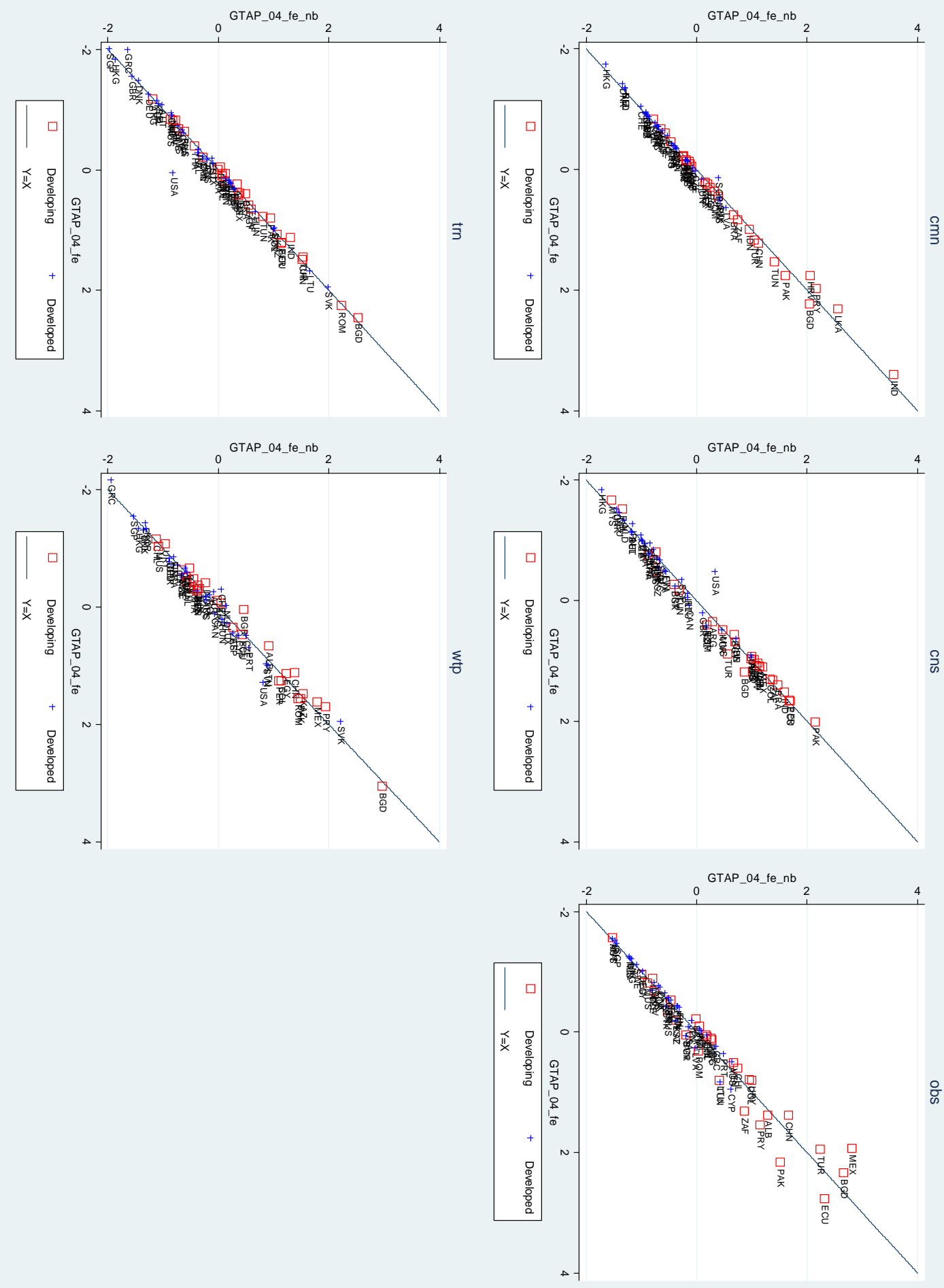
Figure 4 - AVEs. GTAP data versus OECD panel data
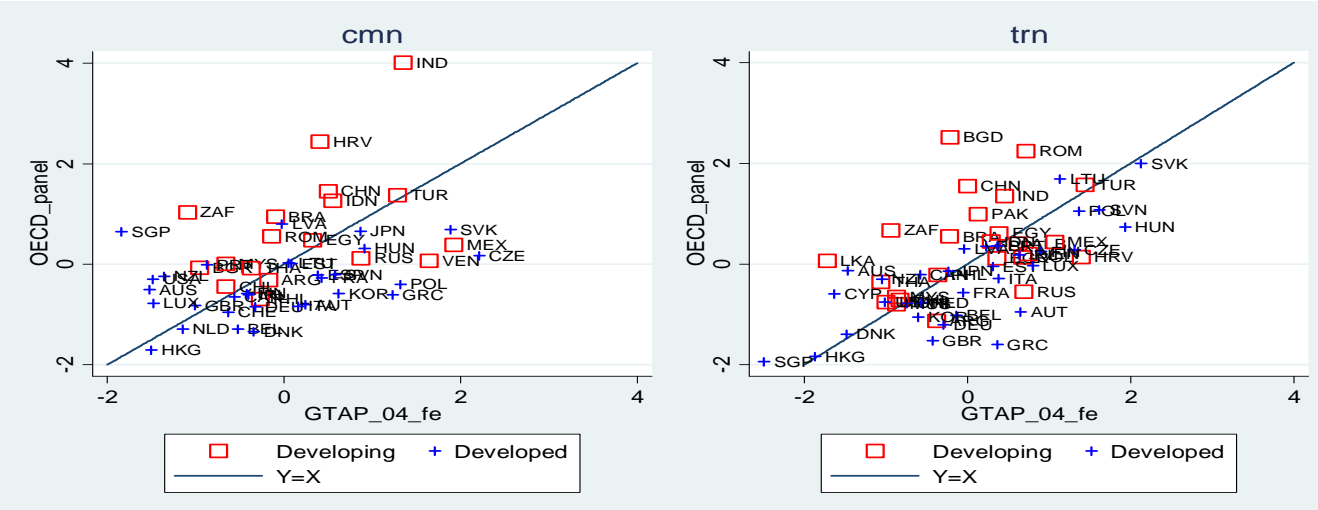

Figure 5 - AVEs. OECD data, panel versus cross section
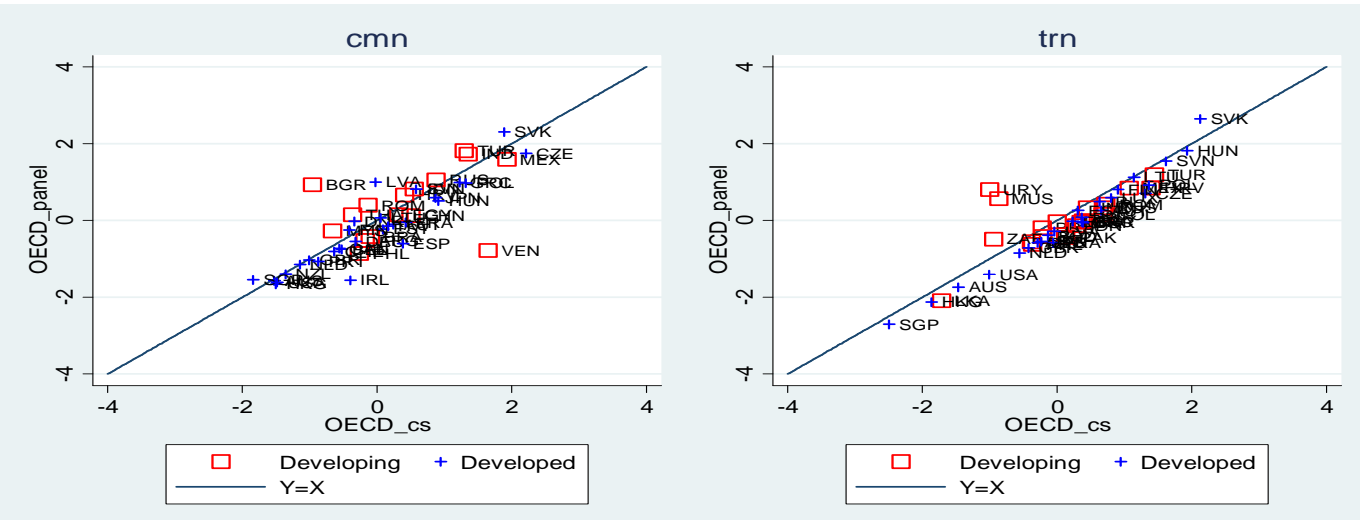


\section{Conclusion}

This research aimed at i) providing tariff equivalents for trade barriers in services based on quantity based methods and ii) assessing the limitations of a method based on gravity and reconstructed data.

We improve on the model proposed in Park (2002) and use a more recent version of the GTAP dataset of trade in services. We obtained tariff equivalents for nine services sectors and 65 countries. Some similarities and differences in the level of protection between countries are worth underlining. The least protected countries are the developed economies. The most liberalized sector is Transport with an average protection of $26 \%$, and the highest barriers are for Construction, with an average tariff of $75 \%$.

The second contribution of this paper is to highlight that the misspecification of the gravity model used can cause systematic bias and underestimate actual trade barriers. In fact compared to Park's estimates, our tariff equivalents are generally higher, except for Transport and Business services where figures are comparable. Relying on OECD panel data for the period 2002-2006, the results obtained are different from those obtained using cross section data from the GTAP dataset. We showed that those differences are due to the data (reconstructed versus actual), not the methodology (cross section versus panel). This should be taken as warning that using partially 'reconstructed data' to estimate tariff equivalents can produce biased results. However, the hierarchy of countries within sectors in terms of protection obtained with the reconstructed data-set is fairly reliable and most divergences related to developing economies. We are therefore quite confident about the accuracy of the tariff equivalents of protection for services trade proposed here.

It would be useful to compare these results with results from alternative methods for estimating the barriers to trade, especially price impact approaches. An example of this approach can be found in a companion paper Fontagné and Mitaritonna (2009) and is applied to developing economies. It highlights that these alternative methods are highly data demanding, which limits their use. 


\section{REFERENCES}

Anderson, J. E. (1979). A theoretical foundation for the gravity equation. American Economic Review, 69(1):106-16.

Anderson, J. E. and van Wincoop, E. (2003). Gravity with Gravitas: A Solution to the Border Puzzle. American Economic Review, 93(1):170-192.

Baldwin, R. and Taglioni, D. (2006). Gravity for dumies and Dummies for Gravity. Working Paper 12516, NBER.

Bergstrand, J. H. (1990). The heckscher-ohlin-samuelson model, the linder hypothesis and the determinants of bilateral intra-industry trade. Economic Journal, 100(403):1216-29.

Borchert, I., Gootiz, B., and Mattoo, A. (2011). Restriction on services trade and fdi in developing countries. Technical report, World Bank.

Chen, Z. and Schembri, L. (2002). Measuring the Barriers to Trade in Services: Literature and Methodologies. Trade policy research, Minister of Public Works and Government Services Canada.

Deardorff, A. V. (1998). Determinants of Bilateral Trade: Does Gravity Work in a Neoclassical World? In The Regionalization of the World Economy. J.A. Frankel.

Decreux, Y. and Fontagné, L. (2011). Economic Impact of Potential Outcome of the DDA. Working Papers 2011-23, CEPII research center.

Dee, P. (2005). A compendium of barriers to trade in services. Technical report, Australian National University. Australian National University.

Dihel, N. and Shepherd, B. (2007). Modal Estimates of Services Barriers. OECD Trade Policy Working Papers 51, OECD Trade Directorate.

Feenstra, R. (2002). Border Effects and the Gravity Equation: Consistent Methods for Estimation. Scottish Journal of Political Economy, 49(5):491-506.

Feenstra, R. (2004). Advanced International Trade: Theory and Evidence. Princeton University Press.

Fontagné, L. and Mitaritonna, C. (2009). Assessing Barriers to Trade in the Distribution and Telecom Sectors in Emerging Countries. Technical report, CEPII research center.

Francois, J. (1993). Explaining the Pattern of Trade in Producer Services. International Economic Journal, 7(3):23-31.

Francois, J., Pindyuk, O., and Woerz, J. (2009). Trends in International Trade and FDI in Services: a global dataset of services trade. Technical Report Discussion paper 2009-08-02, Institute for International and Development Economics.

Francois, J., van Meijl, H., and van Tongeren, F. (2005). Trade liberalization in the Doha Development Round. Economic Policy, 20(42):349-391.

Gootiiz, B. and Mattoo, A. (2009). Services in Doha. What's on the table? World bank Policy Research Paper, 4903.

Head, K., Mayer, T., and Ries, J. (2007). How Remote is the Offshoring Threat? Working Paper 18, CEPII.

Helpman, E. and Krugman, P. (1985). Market Structure and Foreign Trade. Cambridge University Press. 
Helpman, E., Melitz, M., and Rubinstein, Y. (2007). Estimating Trade Flows: Trading Partners and Trading Volumes. NBER Working Papers 12927, National Bureau of Economic Research, Inc.

Hoekman, B. (1996). Assessing the General Agreement on Trade in Services. In The Uruguay Round and the Developing Countries. Cambridge University Press.

Kimura, F. and Lee, H.-H. (2006). The Gravity Equation in International Trade in Services. Review of World Economics, 142(1):92-121.

Kox, H. L. and Nordas, H. K. (2007). Services trade and domestic regulation. MPRA Paper 2116, University Library of Munich, Germany.

Mattoo, A., Rathindran, R., and Subramanian, A. (2001). Measuring services trade liberalization and its impact on economic growth: an illustration. Policy Research Working Paper Series 2655, The World Bank.

Melitz, M. J. and Ottaviano, G. I. P. (2008). Market size, trade, and productivity. Review of Economic Studies, 75(1):295-316.

Mirza, D. and Nicoletti, G. (2004). What's so Special about Trade in Services? Research Paper 2004/02, Leverhulme Centre for Research on Globalisation and Economic Policy.

Park, S.-C. (2002). Measuring Tariff Equivalents in Cross-Border Trade in Services. Trade Working Papers 353, East Asian Bureau of Economic Research.

Stern, R. M. (2000). Quantifying Barriers to Trade in Services. Working Papers 470, Research Seminar in International Economics, University of Michigan.

van Leeuwen, N. and Lejour, A. (2008). The quality of bilateral services trade data. Cpb memoranda, CPB Netherlands Bureau for Economic Policy Analysis.

Walsh, K. (2006). Trade in Services: Does Gravity Hold? A Gravity Model Approach to Estimating Barriers to Services Trade. The Institute for International Integration Studies Discussion Paper Series 183, IIIS.

World-Trade-Organization (2010). World Trade Report. 


\section{Appendix}

\subsection{Cross section estimations using GTAP data}

Table 5 - Estimator OLS, Model 1.1

\begin{tabular}{|c|c|c|c|c|c|c|c|}
\hline \multirow{2}{*}{$\begin{array}{l}\text { Dependent Variable } \\
\text { Sector }\end{array}$} & \multicolumn{7}{|c|}{ Bilateral Services Trade for a given sector in 2004} \\
\hline & $\mathrm{cmn}$ & cns & ofi & obs & $\operatorname{trn}$ & trd & osg \\
\hline \multirow[t]{2}{*}{$\operatorname{lgdp04_{i}}$} & 0.669 & 0.854 & 0.917 & 0.896 & 0.728 & 0.790 & 0.742 \\
\hline & $(53.39)^{* *}$ & $(45.06)^{* *}$ & $(55.40)^{* *}$ & $(67.34)^{* *}$ & $(72.04)^{* *}$ & $(55.66)^{* *}$ & $(58.81)^{* *}$ \\
\hline \multirow[t]{2}{*}{$\operatorname{lgdp04_{j}}$} & 0.774 & 0.779 & 0.813 & 0.709 & 0.787 & 0.813 & 0.824 \\
\hline & $(42.24)^{* *}$ & $(32.35) * *$ & $(39.85)^{* *}$ & $(39.58) * *$ & $(62.14)^{* *}$ & $(46.36)^{* *} *$ & $(55.61)^{* *}$ \\
\hline \multirow[t]{2}{*}{ ldist } & -0.206 & -0.842 & -0.443 & -0.389 & -0.050 & -0.159 & -0.148 \\
\hline & $(8.84)^{* *}$ & $(24.43)^{* *}$ & $(13.45)^{* *}$ & $(15.24)^{* *}$ & $(2.82)^{* * *}$ & $(6.29)^{* *}$ & $(7.22)^{* *}$ \\
\hline \multirow[t]{2}{*}{ comlang-off } & 0.245 & -0.584 & 0.709 & 0.157 & 0.325 & 0.455 & 0.317 \\
\hline & $(2.55)^{*}$ & $(5.10)^{* *}$ & $(5.70)^{* *}$ & $(1.48)$ & $(5.42)^{* *}$ & $(4.30)^{* *}$ & $(3.87)^{* *}$ \\
\hline \multirow[t]{2}{*}{ border } & -0.361 & -0.605 & -0.679 & -0.410 & -0.294 & -0.286 & -0.293 \\
\hline & $(2.52)^{*}$ & $(3.21)^{* *}$ & $(4.01)^{* * *}$ & $(2.81)^{* * *}$ & $(2.85)^{* *}$ & $(1.96)^{*}$ & $(2.75)^{* *}$ \\
\hline \multirow[t]{2}{*}{ bil-sa } & -1.290 & -0.403 & -1.051 & 1.078 & 0.167 & 0.839 & -0.539 \\
\hline & $(4.14)^{* *}$ & $(1.01)$ & $(4.86)^{* * *}$ & $(4.04)^{* *}$ & $(0.94)$ & $(3.00)^{* *}$ & $(2.73)^{* *}$ \\
\hline \multirow[t]{2}{*}{ bil-lac } & 0.239 & -1.483 & -1.327 & -1.671 & -0.332 & -0.829 & -0.417 \\
\hline & $(1.85)$ & $(9.02)^{* *}$ & $(6.58)^{* *}$ & $(8.96)^{* *}$ & $(3.12)^{* *}$ & $(5.35)^{* *}$ & $(3.80)^{* *}$ \\
\hline \multirow[t]{2}{*}{$\operatorname{lppi} 04_{i}$} & -1.771 & -1.951 & -1.456 & -1.686 & -0.912 & -2.138 & -0.743 \\
\hline & $(20.67)^{* *}$ & $(13.59)^{* *}$ & $(13.83)^{* *}$ & $(19.00)^{* *}$ & $(11.40)^{* *}$ & $(17.35)^{* *}$ & $(10.10)^{* *}$ \\
\hline \multirow[t]{2}{*}{$\operatorname{lppi} 04_{j}$} & -1.061 & -1.431 & -0.284 & -1.548 & -0.567 & -0.929 & -0.122 \\
\hline & $(13.92)^{* *}$ & $(15.53)^{* *}$ & $(2.85)^{* *}$ & $(17.89)^{* *} *$ & $(9.14)^{* *}$ & $(11.13)^{* * *}$ & (1.86) \\
\hline \multirow[t]{2}{*}{ Constant } & -7.955 & -6.550 & -19.276 & -6.875 & -15.455 & -10.335 & -20.718 \\
\hline & $(9.12)^{* *}$ & $(5.12)^{* *}$ & $(17.74)^{* *} *$ & $(7.24)^{* *}$ & $(21.44)^{* *}$ & $(9.94)^{* *}$ & $(26.89)^{* *}$ \\
\hline Observations & 2750 & 2750 & 2750 & 2750 & 2750 & 2750 & 2750 \\
\hline R-squared & 0.69 & 0.65 & 0.69 & 0.74 & 0.80 & 0.74 & 0.75 \\
\hline
\end{tabular}

Robust t-statistics in parentheses.

*significant at 5\%; ** significant at $1 \%$. 
Table 6 - Estimator OLS, Model 1.2

\begin{tabular}{|c|c|c|c|c|c|c|c|}
\hline \multirow{2}{*}{$\begin{array}{l}\text { Dependent Variable } \\
\text { Sector }\end{array}$} & \multicolumn{7}{|c|}{ Bilateral Services Trade for a given sector in 2004} \\
\hline & $\mathrm{cmn}$ & cns & ofi & obs & $\operatorname{trn}$ & $\operatorname{trd}$ & osg \\
\hline \multirow[t]{2}{*}{$l g d p 04_{i}$} & 0.938 & 1.108 & 1.354 & 1.217 & 0.915 & 1.057 & 0.888 \\
\hline & $(50.16) * *$ & $(35.75)^{* *}$ & $(65.94)^{* *}$ & $(61.40)^{* *}$ & $(67.00)^{* *}$ & $(50.94)^{* *}$ & $(51.43)^{* *}$ \\
\hline \multirow[t]{2}{*}{$\operatorname{lpib04}_{j}$} & 1.179 & 0.922 & 1.194 & 0.888 & 0.981 & 0.954 & 0.992 \\
\hline & $(51.86)^{* *}$ & $(26.90)^{* *}$ & $(53.72)^{* *}$ & $(38.26)^{* *}$ & $(61.10)^{* *}$ & $(39.17)^{* *}$ & $(51.56)^{* *}$ \\
\hline \multirow[t]{2}{*}{ ldist } & 0.059 & -0.690 & -0.227 & -0.208 & 0.016 & -0.057 & -0.063 \\
\hline & $(2.04)^{*}$ & $(14.13)^{* *}$ & $(6.88)^{* *}$ & $(6.77)^{* *}$ & $(0.69)$ & (1.67) & $(2.25)^{*}$ \\
\hline \multirow[t]{2}{*}{ comlang-off } & -0.370 & -0.111 & 0.328 & -0.445 & -0.231 & 0.123 & -0.495 \\
\hline & $(2.86)^{* *}$ & $(0.54)$ & $(2.18)^{*}$ & $(2.79)^{* *}$ & $(2.26)^{*}$ & $(0.83)$ & $(3.19)^{* * *}$ \\
\hline \multirow[t]{2}{*}{ border } & 0.065 & -0.295 & -0.221 & -0.083 & -0.116 & -0.045 & -0.152 \\
\hline & $(0.63)$ & (1.73) & (1.63) & $(0.70)$ & (1.36) & $(0.32)$ & (1.53) \\
\hline \multirow[t]{2}{*}{ bil-sa } & 0.130 & 0.399 & 0.472 & 2.077 & 0.851 & 1.573 & 0.084 \\
\hline & $(0.48)$ & (1.03) & $(3.44)^{* *}$ & $(9.35)^{* *}$ & $(7.11)^{* *}$ & $(6.40)^{* *}$ & $(0.54)$ \\
\hline \multirow[t]{2}{*}{ bil-lac } & 0.633 & -1.246 & -0.963 & -1.466 & -0.152 & -0.695 & -0.259 \\
\hline & $(5.36)^{* *}$ & $(7.71)^{* *}$ & $(5.42)^{* *}$ & $(8.39)^{* *}$ & (1.65) & $(4.72)^{* *}$ & $(2.44)^{*}$ \\
\hline \multirow[t]{2}{*}{$\operatorname{lppi} 04_{i}$} & -1.094 & -1.283 & -0.377 & -0.832 & -0.482 & -1.455 & -0.387 \\
\hline & $(12.15)^{* *}$ & $(8.45)^{* *}$ & $(3.58)^{* *}$ & $(8.74)^{* *}$ & $(6.66)^{* * *}$ & $(12.36)^{* *}$ & $(5.27)^{* * *}$ \\
\hline \multirow[t]{2}{*}{${\operatorname{lppi} 04_{j}}$} & -0.129 & -1.143 & 0.525 & -1.160 & -0.163 & -0.647 & 0.253 \\
\hline & (1.80) & $(11.22)^{* *}$ & $(5.94)^{* *}$ & $(13.60)^{* *}$ & $(2.54)^{*}$ & $(7.76)^{* *}$ & $(3.67)^{* *}$ \\
\hline \multirow[t]{2}{*}{ comlang-ethno } & 0.486 & -0.614 & 0.234 & 0.590 & 0.463 & 0.308 & 0.777 \\
\hline & $(4.08)^{* *}$ & $(3.06)^{* *}$ & $(1.76)$ & $(3.83)^{* *}$ & $(4.95)^{* *}$ & $(2.38)^{*}$ & $(5.52)^{* *}$ \\
\hline \multirow[t]{2}{*}{ colony } & 0.072 & 0.108 & -0.168 & -0.001 & 0.136 & -0.146 & 0.170 \\
\hline & $(0.67)$ & $(0.64)$ & (1.06) & $(0.01)$ & (1.43) & (1.08) & (1.35) \\
\hline \multirow[t]{2}{*}{$\operatorname{lpop}_{i}$} & -0.401 & -0.358 & -0.635 & -0.469 & -0.277 & -0.387 & -0.223 \\
\hline & $(17.09)^{* *}$ & $(10.80)^{* *}$ & $(27.42)^{* * *}$ & $(20.35)^{* *}$ & $(18.90)^{* *}$ & $(16.42)^{* *}$ & $(13.19)^{* *}$ \\
\hline \multirow[t]{2}{*}{$\operatorname{lpop}_{j}$} & -0.514 & -0.164 & -0.475 & -0.225 & -0.250 & -0.173 & -0.224 \\
\hline & $(26.25) * *$ & $(5.30)^{* *}$ & $(24.33)^{* *}$ & $(10.28)^{* *}$ & $(17.26)^{* *}$ & $(7.94) * *$ & $(13.23)^{* *}$ \\
\hline \multirow[t]{2}{*}{ europe } & 0.138 & 0.112 & -0.229 & 0.116 & -0.272 & -0.102 & -0.090 \\
\hline & $(1.99)^{*}$ & $(0.86)$ & $(2.27)^{*}$ & (1.55) & $(4.04)^{* * *}$ & (1.18) & (1.16) \\
\hline \multirow[t]{2}{*}{ alena } & 0.383 & -1.827 & -0.045 & -1.764 & -0.056 & -1.076 & 0.197 \\
\hline & $(2.65)^{* *}$ & $(5.01)^{* *}$ & $(0.11)$ & $(3.74)^{* *}$ & $(0.49)$ & $(4.95)^{* *}$ & $(0.52)$ \\
\hline \multirow[t]{2}{*}{ anzcerta } & -0.567 & -2.526 & -2.165 & -2.314 & -0.840 & -1.253 & -0.677 \\
\hline & $(4.44)^{* *}$ & $(8.45)^{* *}$ & $(16.29)^{* *}$ & $(18.01)^{* *}$ & $(6.99)^{* *}$ & $(9.69)^{* *}$ & $(3.95)^{* *}$ \\
\hline \multirow[t]{2}{*}{ Constant } & -20.122 & -13.961 & -32.717 & -15.731 & -21.014 & -16.986 & -25.613 \\
\hline & $(21.99)^{* *}$ & $(9.67) * *$ & $(32.30)^{* * *}$ & $(15.78)^{* *}$ & $(28.80)^{* *}$ & $(15.95)^{* *}$ & $(31.17)^{* *}$ \\
\hline Observations & 2750 & 2750 & 2750 & 2750 & 2750 & 2750 & 2750 \\
\hline R-squared & 0.79 & 0.68 & 0.79 & 0.78 & 0.84 & 0.77 & 0.78 \\
\hline
\end{tabular}

Robust t-statistics in parentheses.

*significant at 5\%; ** significant at $1 \%$. 
Table 7 - Estimator OLS, Model 1.3

\begin{tabular}{|c|c|c|c|c|c|c|c|}
\hline \multirow{2}{*}{$\begin{array}{l}\text { Dependent Variable } \\
\text { Sector }\end{array}$} & \multicolumn{7}{|c|}{ Bilateral Services Trade for a given sector in 2004} \\
\hline & $\mathrm{cmn}$ & cns & ofi & obs & $\operatorname{trn}$ & trd & osg \\
\hline \multirow[t]{2}{*}{$\operatorname{lpib04}_{i}$} & 0.943 & 1.109 & 1.346 & 1.211 & 0.915 & 1.059 & 0.888 \\
\hline & $(60.74)^{* *}$ & $(41.67)^{* *}$ & $(79.99)^{* *}$ & $(70.50)^{* *}$ & $(80.98)^{* *}$ & $(63.82)^{* *}$ & $(61.12)^{* *}$ \\
\hline \multirow[t]{2}{*}{$\operatorname{lpib04}_{j}$} & 1.210 & 1.013 & 1.210 & 1.096 & 1.060 & 1.109 & 0.975 \\
\hline & $(75.07)^{* *}$ & $(40.35)^{* *}$ & $(72.94)^{* *}$ & $(60.56)^{* *}$ & $(92.42)^{* *}$ & $(66.23)^{* *}$ & $(70.47)^{* *}$ \\
\hline \multirow[t]{2}{*}{ ldist } & 0.063 & -0.668 & -0.132 & -0.255 & 0.038 & 0.036 & -0.068 \\
\hline & $(2.85)^{* *}$ & $(18.28)^{* *}$ & $(5.19)^{* *}$ & $(10.90)^{* *}$ & $(2.21)^{*}$ & (1.53) & $(3.21)^{* *}$ \\
\hline \multirow[t]{2}{*}{ comlang-off } & -0.361 & -0.118 & 0.333 & -0.464 & -0.146 & 0.092 & -0.439 \\
\hline & $(3.56)^{* *}$ & $(0.72)$ & $(2.54)^{*}$ & $(3.23)^{* * *}$ & (1.73) & $(0.75)$ & $(3.40)^{* *}$ \\
\hline \multirow[t]{2}{*}{ border } & 0.059 & -0.189 & -0.105 & -0.183 & -0.103 & 0.052 & -0.207 \\
\hline & $(0.66)$ & $(1.25)$ & (0.99) & $(1.92)$ & $(1.54)$ & $(0.48)$ & $(2.58)^{* *}$ \\
\hline \multirow[t]{2}{*}{ bil-sa } & 0.188 & 0.560 & 0.629 & 2.286 & 0.972 & 1.913 & 0.046 \\
\hline & $(0.70)$ & (1.48) & $(4.81)^{* * *}$ & $(10.44)^{* *}$ & $(7.96)^{* * *}$ & $(8.03)^{* *}$ & $(0.30)$ \\
\hline \multirow[t]{2}{*}{ bil-lac } & 0.556 & -1.243 & -0.844 & -1.594 & -0.114 & -0.395 & -0.265 \\
\hline & $(4.85)^{* *}$ & $(8.70)^{* *}$ & $(5.60)^{* *}$ & $(10.25)^{* *}$ & $(1.41)$ & $(2.98)^{* *}$ & $(2.80)^{* *}$ \\
\hline \multirow[t]{2}{*}{$\operatorname{lppi04}_{i}$} & -1.075 & -1.318 & -0.425 & -0.863 & -0.509 & -1.461 & -0.373 \\
\hline & $(14.67)^{* *}$ & $(10.32)^{* *}$ & $(5.00)^{* *}$ & $(10.74)^{* *}$ & $(8.44)^{* * *}$ & $(15.32)^{* *}$ & $(5.97)^{* *}$ \\
\hline \multirow[t]{2}{*}{$\operatorname{lppi} 04_{j}$} & -0.032 & -0.791 & 0.515 & -0.603 & -0.069 & -0.414 & 0.145 \\
\hline & $(0.51)$ & $(8.84)^{* *}$ & $(6.90)^{* *}$ & $(7.70)^{* * *}$ & $(1.20)$ & $(5.92)^{* *}$ & $(2.34)^{*}$ \\
\hline \multirow[t]{2}{*}{ comlang-ethno } & 0.457 & -0.621 & 0.251 & 0.640 & 0.423 & 0.319 & 0.766 \\
\hline & $(5.02)^{* *}$ & $(4.05)^{* *}$ & $(2.27)^{*}$ & $(4.61)^{* * *}$ & $(5.41)^{* *}$ & $(2.98)^{* *}$ & $(6.61)^{* * *}$ \\
\hline \multirow[t]{2}{*}{ colony } & 0.058 & 0.214 & -0.225 & -0.084 & 0.193 & -0.084 & 0.098 \\
\hline & $(0.65)$ & (1.48) & $(1.72)$ & $(0.70)$ & $(2.49)^{*}$ & $(0.69)$ & $(0.96)$ \\
\hline \multirow[t]{2}{*}{$\operatorname{lpop}_{i}$} & -0.405 & -0.347 & -0.628 & -0.464 & -0.278 & -0.397 & -0.217 \\
\hline & $(21.13) * *$ & $(12.15)^{* *}$ & $(33.42)^{* * *}$ & $(23.46)^{* *}$ & $(22.89)^{* *}$ & $(21.07)^{* *}$ & $(15.26)^{* *}$ \\
\hline \multirow[t]{2}{*}{$\operatorname{lpop}_{j}$} & -0.462 & -0.184 & -0.436 & -0.269 & -0.263 & -0.241 & -0.183 \\
\hline & $(27.75)^{* *}$ & $(6.85)^{* *}$ & $(24.83)^{* *}$ & $(13.43)^{* *}$ & $(20.99)^{* *}$ & $(13.20)^{* *}$ & $(12.22)^{* *}$ \\
\hline \multirow[t]{2}{*}{ europe } & 0.100 & 0.191 & -0.098 & -0.055 & -0.314 & -0.033 & -0.088 \\
\hline & (1.79) & (1.86) & (1.19) & $(0.91)$ & $(6.08)^{* *}$ & $(0.54)$ & (1.47) \\
\hline \multirow[t]{2}{*}{ alena } & 0.343 & -1.934 & 0.009 & -1.982 & -0.111 & -1.124 & 0.211 \\
\hline & $(2.22)^{*}$ & $(5.37)^{* * *}$ & $(0.02)$ & $(4.40)^{* *}$ & (1.07) & $(4.76)^{* *}$ & $(0.56)$ \\
\hline \multirow[t]{2}{*}{ anzcerta } & -0.413 & -2.373 & -1.943 & -2.237 & -0.799 & -1.091 & -0.661 \\
\hline & $(4.75)^{* *}$ & $(9.46)^{* *}$ & $(13.47)^{* *}$ & $(20.65)^{* *}$ & $(5.06)^{* *}$ & $(10.23)^{* *}$ & $(3.83)^{* *}$ \\
\hline \multirow[t]{2}{*}{ Constant } & -22.533 & -18.030 & -34.375 & -22.604 & -23.460 & -21.798 & -25.482 \\
\hline & $(33.32)^{* *}$ & $(16.16)^{* *}$ & $(45.89)^{* *}$ & $(29.46)^{* *}$ & $(42.88)^{* *} *$ & $(28.41)^{* *}$ & $(41.10)^{* *}$ \\
\hline Observations & 4094 & 4094 & 4158 & 4094 & 4094 & 4158 & 4158 \\
\hline R-squared & 0.82 & 0.68 & 0.81 & 0.80 & 0.87 & 0.81 & 0.80 \\
\hline
\end{tabular}

Robust t-statistics in parentheses.

*significant at 5\%; ** significant at $1 \%$. 


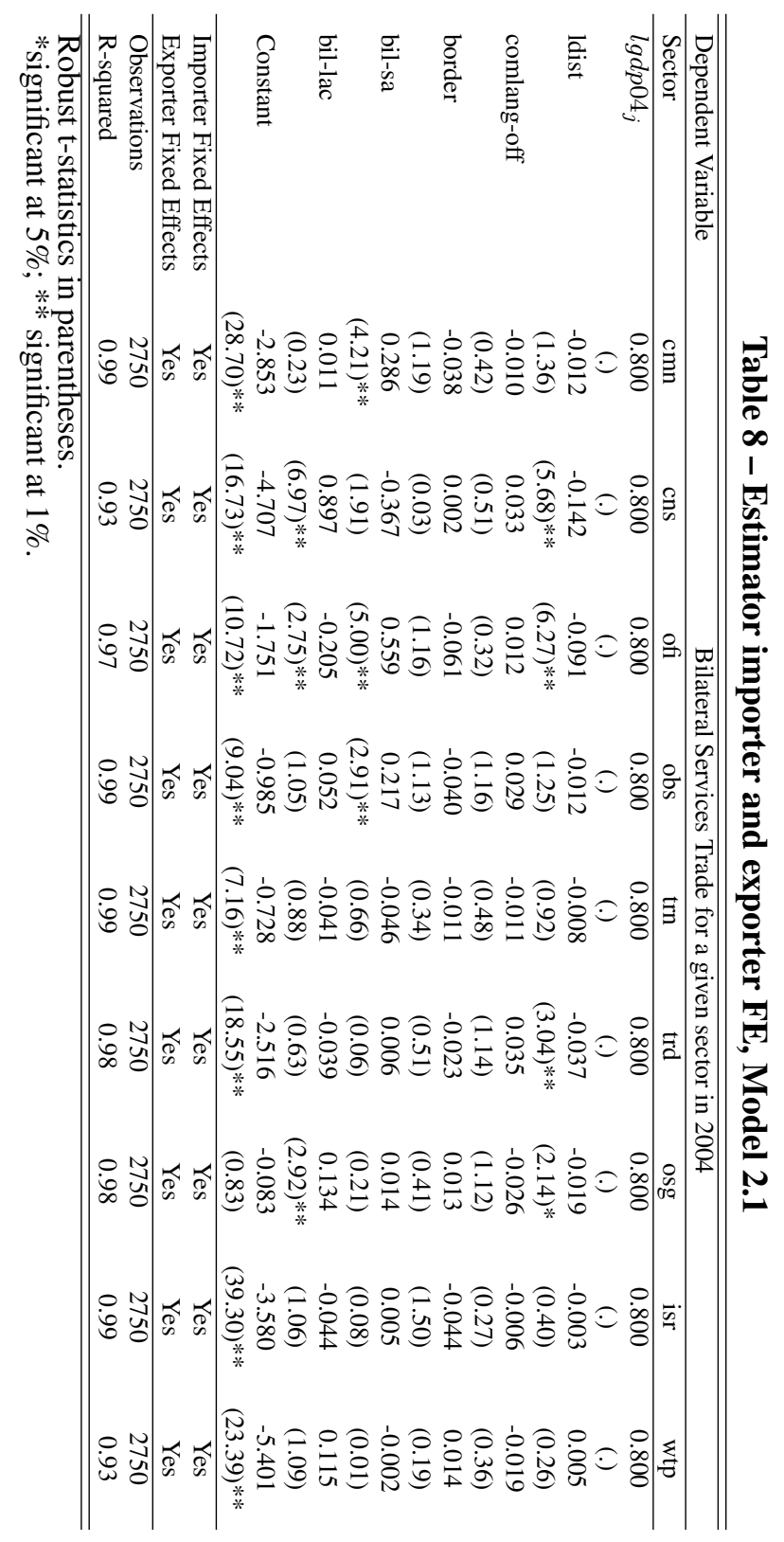




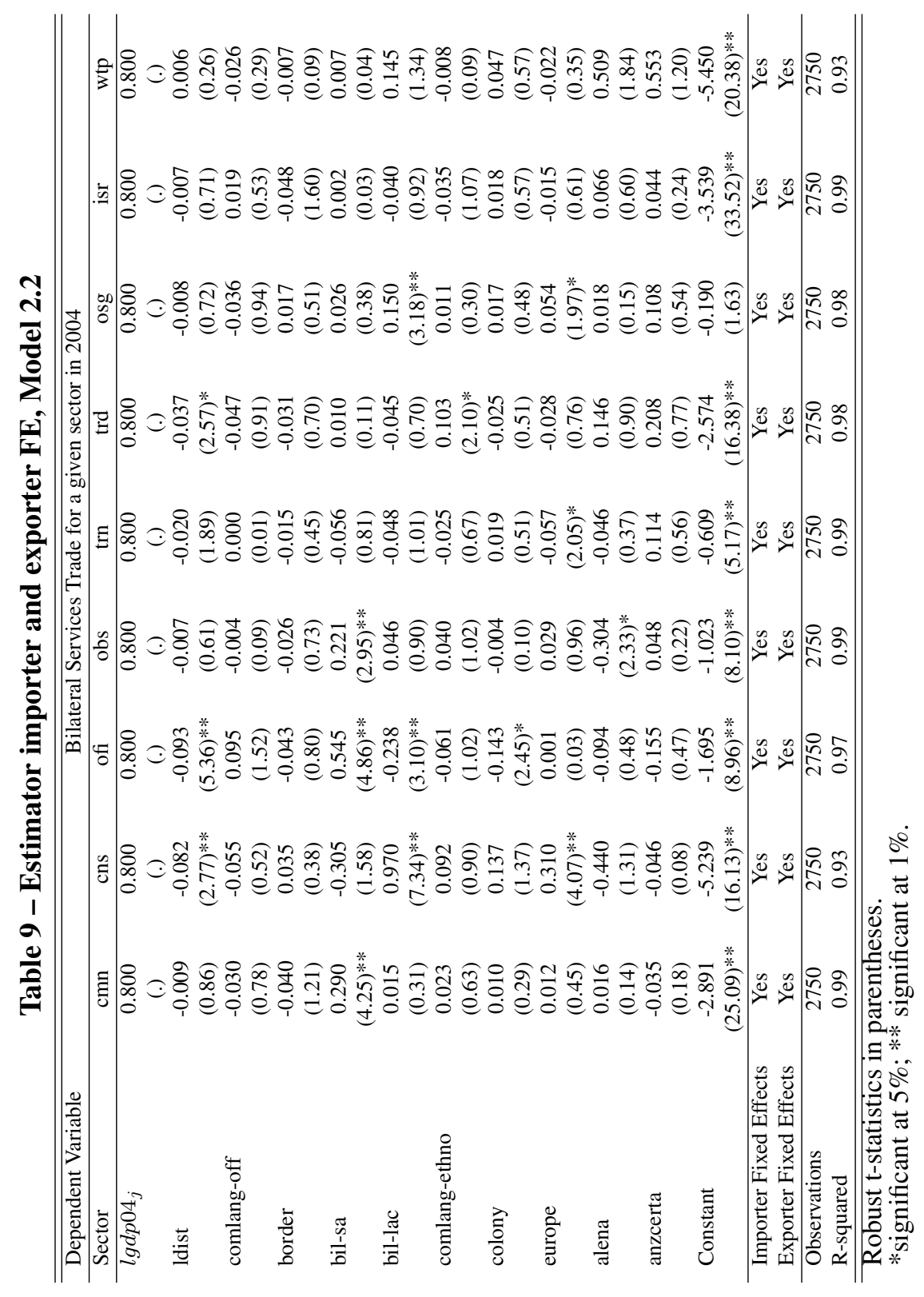


8.2. Ad-valorem equivalents by country from cross section estimations using GTAP data

Table 10 - AVE derived from Model 2.3

(Percent)

\begin{tabular}{|c|c|c|c|c|c|c|c|c|c|}
\hline Country & $\mathrm{cmn}$ & cns & ofi & isr & obs & osg & $\operatorname{trd}$ & $\operatorname{trn}$ & wtp \\
\hline ALB & 44.5 & 126.9 & 95.4 & 24.9 & 86.5 & 28.7 & 59.6 & 35.0 & 102.5 \\
\hline ARG & 36.4 & 93.2 & 38.0 & 30.4 & 55.4 & 20.5 & 43.0 & 11.8 & 68.8 \\
\hline AUS & 31.5 & 126.8 & 64.2 & 44.9 & 66.6 & 44.4 & 64.5 & 26.8 & 61.2 \\
\hline AUT & 23.4 & 25.4 & 23.3 & 16.1 & 0.0 & 26.4 & 24.4 & 14.5 & 67.0 \\
\hline BEL & 10.7 & 25.5 & 0.0 & 21.6 & 9.9 & 19.5 & 23.7 & 13.5 & 55.7 \\
\hline BGD & 113.5 & 120.3 & 99.1 & 50.9 & 128.7 & 58.5 & 125.2 & 68.1 & 175.9 \\
\hline BGR & 43.2 & 60.8 & 48.3 & 50.4 & 40.9 & 51.0 & 71.0 & 30.5 & 86.4 \\
\hline BRA & 71.1 & 148.3 & 54.9 & 53.2 & 46.2 & 36.8 & 70.7 & 37.2 & 51.0 \\
\hline CAN & 27.5 & 73.9 & 33.8 & 16.8 & 31.3 & 35.9 & 51.2 & 25.7 & 67.2 \\
\hline CHE & 19.5 & 113.2 & 39.8 & 46.8 & 52.6 & 35.8 & 52.7 & 17.0 & 71.5 \\
\hline CHL & 33.0 & 133.3 & 105.6 & 48.3 & 69.9 & 40.3 & 45.9 & 18.1 & 29.3 \\
\hline $\mathrm{CHN}$ & 85.2 & 45.6 & 92.6 & 40.7 & 98.1 & 59.6 & 32.9 & 52.8 & 119.1 \\
\hline $\mathrm{COL}$ & 43.3 & 142.4 & 48.3 & 32.4 & 76.4 & 49.8 & 70.8 & 30.9 & 110.5 \\
\hline CYP & 48.5 & 126.1 & 95.6 & 27.5 & 65.8 & 35.3 & 55.3 & 19.9 & 83.2 \\
\hline CZE & 49.6 & 32.7 & 34.9 & 44.3 & 22.4 & 41.5 & 50.2 & 33.2 & 87.6 \\
\hline DEU & 22.3 & 15.0 & 30.4 & 39.3 & 16.6 & 23.7 & 18.8 & 10.8 & 38.1 \\
\hline DNK & 9.4 & 12.7 & 19.3 & 14.0 & 26.4 & 12.1 & 35.0 & 7.9 & 21.2 \\
\hline ECU & 46.3 & 158.2 & 94.2 & 62.3 & 118.0 & 54.9 & 33.6 & 47.2 & 85.3 \\
\hline EGY & 58.1 & 111.8 & 70.6 & 19.9 & 16.0 & 10.8 & 68.3 & 38.1 & 113.6 \\
\hline ESP & 39.2 & 88.4 & 47.9 & 41.2 & 29.2 & 56.7 & 59.0 & 34.2 & 79.3 \\
\hline EST & 45.4 & 34.5 & 63.7 & 76.1 & 35.2 & 18.9 & 61.5 & 28.1 & 22.3 \\
\hline FIN & 29.5 & 54.0 & 109.8 & 66.5 & 36.9 & 50.4 & 52.1 & 32.7 & 40.8 \\
\hline FRA & 37.6 & 36.4 & 50.7 & 61.7 & 35.6 & 39.8 & 42.0 & 20.3 & 40.9 \\
\hline GBR & 23.0 & 84.9 & 19.6 & 36.0 & 30.9 & 16.0 & 34.6 & 6.1 & 38.0 \\
\hline GRC & 28.6 & 48.3 & 68.8 & 39.9 & 57.8 & 25.9 & 49.5 & 5.0 & 0.0 \\
\hline HKG & 0.0 & 0.0 & 6.7 & 6.1 & 10.6 & 0.0 & 16.2 & 1.5 & 18.1 \\
\hline HRV & 113.7 & 130.4 & 105.0 & 92.8 & 23.4 & 63.9 & 72.3 & 31.0 & 53.6 \\
\hline HUN & 53.6 & 46.1 & 44.3 & 46.8 & 36.1 & 45.8 & 31.3 & 40.1 & 72.0 \\
\hline IDN & 80.0 & 112.9 & 95.3 & 38.1 & 22.2 & 38.3 & 29.1 & 35.6 & 56.2 \\
\hline IND & 160.3 & 153.8 & 136.8 & 47.1 & 48.4 & 68.4 & 58.6 & 49.6 & 61.6 \\
\hline IRL & 28.8 & 72.3 & 8.9 & 4.5 & 1.4 & 37.7 & 0.0 & 31.7 & 61.9 \\
\hline IRN & - & - & 125.0 & 48.4 & - & 43.3 & 97.8 & - & - \\
\hline ITA & 22.5 & 33.6 & 65.2 & 39.9 & 32.6 & 33.5 & 29.2 & 24.5 & 43.5 \\
\hline JPN & 63.1 & 25.7 & 61.0 & 45.1 & 43.9 & 48.4 & 42.3 & 26.7 & 48.2 \\
\hline KAZ & 55.4 & - & 86.5 & 53.1 & 35.2 & 55.5 & 84.1 & 46.1 & 124.8 \\
\hline KGZ & 39.3 & 46.5 & 74.6 & 39.3 & 43.5 & 78.6 & 148.3 & 71.7 & 198.7 \\
\hline KOR & 29.2 & 101.6 & 67.2 & 67.2 & 25.5 & 36.2 & 49.0 & 13.0 & 23.2 \\
\hline LKA & 129.3 & 126.2 & 110.6 & 29.7 & 52.0 & 48.4 & 54.0 & 29.7 & 48.9 \\
\hline LTU & 45.7 & 72.3 & 98.4 & 65.7 & 59.7 & 53.8 & 80.5 & 55.0 & 101.7 \\
\hline LUX & 24.2 & 40.2 & 12.3 & 33.8 & 23.1 & 35.2 & 40.3 & 28.4 & 75.5 \\
\hline
\end{tabular}




\begin{tabular}{|c|c|c|c|c|c|c|c|c|c|}
\hline Country & $\mathrm{cmn}$ & cns & ofi & isr & obs & osg & $\operatorname{trd}$ & $\operatorname{trn}$ & wtp \\
\hline LVA & 67.1 & 53.4 & 49.1 & 32.7 & 45.9 & 30.1 & 68.6 & 33.4 & 49.3 \\
\hline MEX & 55.5 & 135.8 & 52.6 & 0.0 & 133.6 & 38.9 & 50.6 & 35.5 & 133.6 \\
\hline MUS & 62.9 & 101.9 & 60.2 & 27.2 & 19.3 & 36.0 & 47.8 & 16.8 & 31.1 \\
\hline MYS & 45.2 & 8.4 & 51.8 & 41.2 & 0.1 & 31.6 & 57.3 & 19.0 & 46.0 \\
\hline NLD & 10.7 & 18.7 & 29.5 & 34.2 & 9.1 & 20.2 & 19.9 & 17.1 & 75.1 \\
\hline NZL & 38.4 & 88.1 & 70.5 & 47.1 & 49.3 & 45.4 & 62.7 & 24.2 & 45.9 \\
\hline PAK & 100.0 & 180.2 & 90.3 & 78.3 & 93.3 & 47.9 & 87.2 & 44.1 & 123.2 \\
\hline PER & 56.9 & 159.1 & 73.7 & 37.6 & 54.7 & 44.4 & 100.3 & 47.1 & 109.0 \\
\hline PHL & 26.4 & 17.6 & 58.5 & 39.5 & 52.4 & 58.9 & 50.1 & 25.6 & 49.6 \\
\hline POL & 34.3 & 43.8 & 64.6 & 27.6 & 48.2 & 59.8 & 85.9 & 45.0 & 64.2 \\
\hline PRT & 44.8 & 61.7 & 58.4 & 55.4 & 61.9 & 41.1 & 55.2 & 34.3 & 89.5 \\
\hline PRY & 117.0 & 131.9 & 62.9 & 18.3 & 82.1 & 32.4 & 75.6 & 31.8 & 139.3 \\
\hline ROM & 60.3 & 88.5 & 71.2 & 68.0 & 47.8 & 67.1 & 96.6 & 63.7 & 121.2 \\
\hline RUS & 48.1 & 44.9 & 71.7 & 37.2 & 30.7 & 42.1 & 43.7 & 20.6 & 56.2 \\
\hline SGP & 62.9 & 67.8 & 52.6 & 5.4 & 2.3 & 15.0 & 3.9 & 0.0 & 14.7 \\
\hline SVK & 63.9 & 40.6 & 55.3 & 62.6 & 29.5 & 60.8 & 45.4 & 59.9 & 148.8 \\
\hline SVN & 39.5 & 49.3 & 70.8 & 73.5 & 41.0 & 54.3 & 56.6 & 45.3 & 101.0 \\
\hline SWE & 22.5 & 40.2 & 37.9 & 40.6 & 13.3 & 35.9 & 37.1 & 18.7 & 46.1 \\
\hline THA & 43.0 & 39.6 & 79.6 & 14.4 & 32.5 & 33.3 & 30.3 & 23.4 & 53.9 \\
\hline TUN & 93.9 & 65.1 & 63.3 & 42.3 & 59.6 & 30.1 & 66.6 & 42.2 & 57.8 \\
\hline TUR & 83.0 & 106.4 & 48.0 & 63.2 & 115.8 & 50.0 & 67.5 & 53.2 & 71.7 \\
\hline URY & 30.8 & 128.9 & 57.3 & 33.6 & 77.6 & 28.9 & 69.2 & 17.4 & 35.5 \\
\hline USA & 36.9 & 95.4 & 51.3 & 43.7 & 42.3 & 8.8 & 61.5 & 17.5 & 98.4 \\
\hline VEN & 46.8 & 133.1 & 63.6 & 50.5 & 67.1 & 34.2 & 64.8 & 31.8 & 56.0 \\
\hline ZAF & 73.4 & 144.0 & 116.2 & 36.2 & 73.2 & 51.3 & 70.1 & 39.0 & 79.2 \\
\hline
\end{tabular}




\subsection{Reliability}

Table 11 - Original Input-0utput data

\begin{tabular}{|c|c|c|}
\hline Country & Year of original matrix & Split \\
\hline Albania & 2000 & transport* \\
\hline Argentina & 2000 & none \\
\hline Australia & 1997 & transport** \\
\hline Austria & 1983 & none \\
\hline Bangladesh & 1994 & transport** \\
\hline Belgium & 1995 & none \\
\hline Bulgaria & 1996 & none \\
\hline Bostwana & 1994 & transport, finance, insurance* \\
\hline Canada & 1990 & no available \\
\hline China & 1997 & none \\
\hline Croatia & 1995 & none \\
\hline Cyprus & 1986 & none \\
\hline Czech Republic & 1996 & none \\
\hline Denmark & 1992 & none \\
\hline Estonia & 1997 & none \\
\hline Finland & 1995 & none \\
\hline France & 1992 & none \\
\hline Germany & 1995 & none \\
\hline Greece & 1995 & none \\
\hline Hungary & 1991 & transport, business $* *$ \\
\hline Hong Kong & 1988 & no available \\
\hline India & 1994 & transport, business* \\
\hline Indonesia & 1995 & transport** \\
\hline Ireland & 1990 & none \\
\hline Italy & 1992 & none \\
\hline Japan & 2000 & no available \\
\hline Korea & 2000 & none \\
\hline Latvia & 1997 & none \\
\hline Lithuania & 1997 & none \\
\hline Luxembourg & 1995 & none \\
\hline Madagascar & 1999 & no available \\
\hline Malaysia & 1995 & transport $* *$ \\
\hline Malawi & 1994 & transport, finance, insurance* \\
\hline Malta & 1996 & none \\
\hline Morocco & 1990 & no available \\
\hline Mozambique & 1995 & all* \\
\hline Netherlands & 2001 & none \\
\hline New Zealand & 1996 & none \\
\hline Peru & 1989 & no available \\
\hline Philippines & 1989 & transport $* *$ \\
\hline Poland & 1997 & none \\
\hline
\end{tabular}

Continued on next page 


\begin{tabular}{lll}
\hline Country & Year of original matrix & Split \\
\hline Portugal & 1993 & none \\
Russian Federation & 1997 & transport, finance, insurance** \\
Romania & 1997 & none \\
Singapore & 1996 & transport** \\
Slovakia & 1997 & none \\
Slovenia & 1997 & none \\
South Africa & 1995 & transport, finance, insurance* \\
Spain & 1994 & none \\
Sri Lanka & 1989 & no available \\
Sweden & 1985 & none \\
Switzerland & 1990 & transport** \\
Taiwan & 1999 & transport** \\
Tanzania & 1992 & all* \\
Thailand & 1995 & transport** \\
Tunisia & 1995 & none \\
Turkey & 1995 & none \\
Uganda & 1992 & finance** \\
United Kingdom & 1990 & other services, recreational ser- \\
& & vices, business* \\
Uruguay & 1983 & none \\
Venezuela & 1986 & no available \\
Zambia & 1995 & all* \\
Zimbabwe & 1991 & all* \\
& & \\
\hline \hline Sorce: & & \\
\hline
\end{tabular}

Source: Note: Gtap documentations provide all the information.

*: the different weights are notified.

**: no information on the weights. 


\subsection{RTAs}

Table 12 - Regional Trade Agreements

\begin{tabular}{ll}
\hline \hline Region & Members \\
\hline NAFTA & Canada, Mexico, United States \\
Europe & Belgium, France, Germany, Italy, Luxembourg, Netherlands, \\
& Denmark, Ireland, United Kingdom, Greece, Portugal, Spain, \\
& Austria, Finland, Sweden, Bulgaria, Czech Republic, Cyprus, \\
& Estonia, Hungary, Latvia, Lithuania, Malta, Poland, Slovakia, \\
& Slovenia, Romania, Bulgaria \\
ASEAN (bil-sa) & Indonesia, Malaysia, Philippines, Singapour, Thailand, \\
& Brunei(1984), Vietnam(1995), Laos(1997), Myanmar(1997), \\
ANZCERTA & Cambodia(1999) \\
\hline \hline
\end{tabular}


LIST OF WORKING PAPERS RELEASED BY CEPII

An Exhaustive list is available on the website: |lwww.cepii.fr.

No

2011-23 Economic Impact of Potential Outcome of the DDA

2011-22 More Bankers, more Growth? Evidence from OECD Countries

2011-21 EMU, EU, Market Integration and Consumption Smoothing

2011-20 Real Time Data and Fiscal Policy Analysis

2011-19 On the inclusion of the Chinese renminbi in the SDR basket

2011-18 Unilateral trade reform, Market Access and Foreign Competition: the Patterns of Multi-Product Exporters

2011-17 The "Forward Premium Puzzle" and the Sovereign Default Risk

2011-16 Occupation-Eduction Mismatch of Immigrant Workers in Europe: Context and Policies

2011-15 Does Importing More Inputs Raise Exports? Firm Level Evidence from France

2011-14 Joint Estimates of Automatic and Discretionary Fiscal Policy: the OECD 1981-2003

2011-13 Immigration, vieillissement démographique et financement de la protection sociale : une évaluation par l'équilibre général calculable appliqué à la France

2011-12 The Performance of Socially Responsible Funds: Does the Screening Process Matter?

\section{Authors}

Y. Decreux \& L. Fontagné

G. Capelle-Blancard \& C. Labonne

A. Christev \& J. Mélitz J. Cimadomo

A. Bénassy-Quéré \& D. Capelle

M. Bas \& P. Bombarda

V. Coudert \& V. Mignon M. Aleksynska \& A. Tritah

M. Bas \& V. Strauss-Kahn

J. Darby \& J. Mélitz

X. Chojnicki \& L. Ragot

G. Capelle-Blancard \& S. Monjon 
No

Tittle

2011-11 Market Size, Competition, and the Product Mix of Exporters

2011-10 The Trade Unit Values Database

2011-09 Carbon Price Drivers: Phase I versus Phase II Equilibrium

2011-08 Rebalancing Growth in China: An International Perspective

2011-07 Economic Integration in the EuroMed: Current Status and Review of Studies

2011-06 The Decision to Import Capital Goods in India: Firms' Financial Factors Matter

2011-05 FDI from the South: the Role of Institutional Distance and Natural Resources

2011-04b What International Monetary System for a fastchanging World Economy?

2011-04a Quel système monétaire international pour une économie mondiale en mutation rapide?

2011-03 China's Foreign Trade in the Perspective of a more Balanced Economic Growth

2011-02 The Interactions between the Credit Default Swap and the Bond Markets in Financial Turmoil

2011-01 Comparative Advantage and Within-Industry Firms Performance

2010-33 Export Performance and Credit Constraints in China

2010-32 Export Performance of China's domestic Firms: The Role of Foreign Export Spillovers

2010-31 Wholesalers in International Trade

\section{Authors}

T. Mayer, M. Melitz \& G. Ottaviano

A. Berthou \& C. Emlinger

A. Creti, P.-A. Jouvet \& V. Mignon

A. Bénassy-Quéré, B. Carton \& L. Gauvin

J. Jarreau

A. Berthou \& M. Bas

M. Aleksynska \& O. Havrylchyk

A. Bénassy-Quéré \& J. Pisani-Ferry

A. Bénassy-Quéré \& J. Pisani-Ferry

G. Gaulier, F. Lemoine \& D. Ünal

V. Coudert \& M. Gex

M. Crozet \& F. Trionfetti

J. Jarreau \& S. Poncet

F. Mayneris \& S. Poncet

M. Crozet, G. Lalanne $\&$ S. Poncet 
No

\section{Tittle}

2010-30 TVA et taux de marge : une analyse empirique sur données d'entreprises

2010-29 Economic and Cultural Assimilation and Integration of Immigrants in Europe

2010-28 Les firmes françaises dans le commerce de service

2010-27 The world Economy in 2050: a Tentative Picture

2010-26 Determinants and Pervasiveness of the Evasion of Customs Duties

2010-25 On the Link between Credit Procyclicality and Bank Competition

2010-24 Are Derivatives Dangerous? A Literature Survey

2010-23 BACI: International Trade Database at the ProductLevel - The 1994-2007 Version

2010-22 Indirect Exporters

2010-21 Réformes des retraites en France: évaluation de la mise en place d'un système par comptes notionnels

2010-20 The Art of Exceptions: Sensitive Products in the Doha Negotiations

2010-19 Measuring Intangible Capital Investment: an Application to the "French Data"

2010-18 Clustering the Winners: The French Policy of Competitiveness Clusters

2010-17 The Credit Default Swap Market and the Settlement of Large Defauts

\section{Authors}

P. Andra, M. Carré \& A. Bénassy-Quéré

M. Aleksynska \& Y. Algan

G. Gaulier, E. Milet \& D. Mirza

J. Fouré, A. Bénassy-Quéré \& L. Fontagné

S. Jean

\& C. Mitaritonna

V. Bouvatier, A. Lopez-Villavicencio \& V. Mignon

G. Capelle-Blancard

G. Gaulier \& Soledad Zignago

F. McCann

X. Chojnicki \& R. Magnani

C. Gouel, C. Mitaritonna \& M.P. Ramos V. Delbecque \& L. Nayman

L. Fontagné, P. Koenig, F. Mayneris \&S. Poncet

V. Coudert \& M. Gex 
No

Tittle

2010-16 The Impact of the 2007-10 Crisis on the Geography of Finance

2010-15 Socially Responsible Investing: It Takes more than Words

2010-14 A Case for Intermediate Exchange-Rate Regimes

2010-13 Gold and Financial Assets: Are they any Safe Havens in Bear Markets?

2010-12 European Export Performance

2010-11 The Effects of the Subprime Crisis on the Latin American Financial Markets: An Empirical Assessment

2010-10 Foreign Bank Presence and its Effect on Firm Entry and Exit in Transition Economies

2010-09 The Disorted Effect of Financial Development on International Trade Flows

2010-08 Exchange Rate Flexibility across Financial Crises

2010-07 Crises and the Collapse of World Trade: The Shift to Lower Quality

2010-06 The heterogeneous effect of international outsourcing on firm productivity

2010-05 Fiscal Expectations on the Stability and Growth Pact: Evidence from Survey Data

2010-04 Terrorism Networks and Trade: Does the Neighbor Hurt

2010-03 Wage Bargaining and the Boundaries of the Multinational Firm

2010-02 Estimation of Consistent Multi-Country FEERs

2010-01 The Elusive Impact of Investing Abroad for Japanese Parent Firms: Can Disaggregation According to FDI Motives Help

\section{Authors}

G. Capelle-Blancard \& Y. Tadjeddine

G. Capelle-Blancard \& S. Monjon

V. Salins \& A. Bénassy-Quéré

V. Coudert \& H. Raymond

A. Cheptea, L. Fontagné \& S. Zignago

G. Dufrénot, V. Mignon \& A. Péguin-Feissolle

O. Havrylchyk

A. Berthou

V. Coudert, C. Couharde \& V. Mignon

A. Berthou \& C. Emlinger

Fergal McCann

M. Poplawski-Ribeiro \& J.C. Rüle

J. de Sousa, D. Mirza \& T. Verdier

M. Bas \& J. Carluccio

B. Carton \& K. Hervé

L. Hering, T. Inui \& S. Poncet 
Organisme public d'étude et de recherche en économie internationale, le CEPII est placé auprès du Centre d'Analyse Stratégique. Son programme de travail est fixé par un conseil composé de responsables de l'administration et de personnalités issues des entreprises, des organisations syndicales et de l'Université.

Les documents de travail du CEPII mettent à disposition du public professionnel des travaux effectués au CEPII, dans leur phase d'élaboration et de discussion avant publication définitive. Les documents de travail sont publiés sous la responsabilité de la direction du CEPII et n'engagent ni le conseil du Centre, ni le Centre d'Analyse Stratégique. Les opinions qui y sont exprimées sont celles des auteurs.

Les documents de travail du CEPII sont disponibles sur le site : http//www.cepii.fr. 